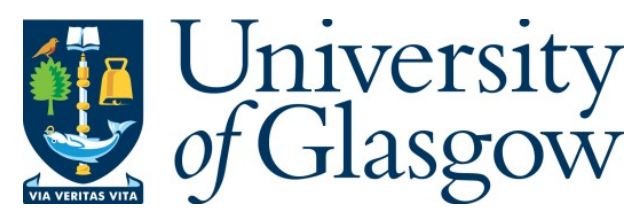

O'Shea, O., Meadows, M., Wrigglesworth, E., Newton, J. and Hawkes, L. (2020) Novel insights into the diet of southern stingrays and Caribbean whiptail rays. Marine Ecology Progress Series, 655, pp. 157-170.

(doi: $10.3354 / \operatorname{meps} 13529)$

This is the Author Accepted Manuscript.

There may be differences between this version and the published version. You are advised to consult the publisher's version if you wish to cite from it.

http://eprints.gla.ac.uk/229096/

Deposited on: 22 January 2021

Enlighten - Research publications by members of the University of Glasgow http://eprints.gla.ac.uk 


\section{Novel insights into the diet of southern stingrays and Caribbean whiptail rays}

2

3 Running page head: Southern stingray and Caribbean whiptail diet

4

5 Owen R. O’Shea ${ }^{1,2 *}$, Molly H. Meadows ${ }^{3}$, Ethan E. Wrigglesworth ${ }^{3}$, Jason Newton ${ }^{4}$ and Lucy 6 A. Hawkes 5

7

$8{ }^{1}$ Shark Research and Conservation Program, The Cape Eleuthera Institute, Eleuthera, Bahamas

$9 \quad{ }^{2}$ The Centre for Ocean Research and Education, Po Box 255-16, Gregory Town, Eleuthera, 10 The Bahamas

113 University of Exeter, Centre for Ecology and Conservation, College of Life and 12 Environmental Sciences, Penryn Campus, Cornwall TR10 9FE, UK;

$13{ }^{4}$ NERC Life Sciences Mass Spectrometry Facility, SUERC, Rankine Avenue, East Kilbride, 14 Glasgow G75 0QF, UK;

$15{ }^{5}$ University of Exeter, College of Life and Environmental Sciences, Environmental Biology 16 Group, Hatherly Laboratories, Exeter, EX4 4PS, UK

17

$18 *$ Corresponding author $\underline{\text { Owen@coresciences.org }}$

20 Key words: Atlantic chupare, Bahamas, diet composition, elasmobranch, gastric lavage, 21 foraging, trophic ecology 


\section{ABSTRACT}

2 Caribbean whiptail and southern stingrays are large bodied mesopredators, occupying shallow,

3 nearshore ecosystems of The Bahamas, yet virtually nothing is known of their diet or potential

4 resource competition. We used stomach content analysis via gastric lavage and stable isotope

5 analysis to investigate the diet of 94 Caribbean whiptail rays (Styracura schmardae) and 112

6 southern stingrays (Hypanus americanus) across three locations in the central Bahamas.

7 Gastric lavage was used to identify prey consumed, and compared to stable isotope analysis of

$8 \quad \delta^{15} \mathrm{~N}, \delta^{13} \mathrm{C}$ and $\delta^{34} \mathrm{~S}$ of barb, muscle, blood and skin, representing different temporal integration

9 periods. Both species appeared to consume a majority of crustaceans and annelids, although

$10 \quad \delta^{13} \mathrm{C}$ values suggested that Caribbean whiptail rays have larger isotopic niche space across

11 isotopes sampled (potentially broader diet) than southern stingrays, ranging from 5.82 to 3.43

$12 \%^{2}$, and a greater variance in $\delta^{13} \mathrm{C}$, This suggests Caribbean whiptail rays potentially feed on

13 prey from either a wider geographic range, or from different habitats. Caribbean whiptail and

14 southern stingrays are known to spatio-temporally overlap, and their isotopic niche overlapped

15 by $35.6 \%$. This study represents the first integrated diet estimate for southern stingrays using

16 multiple techniques, and the first ever diet assessment in Caribbean whiptail rays. These data

17 are critical for conservation of coastal ray species and management of coastal and nearshore

18 environments throughout the region. 


\section{1. INTRODUCTION}

2 Coastal and nearshore environments in the tropics support highly biodiverse and

3 interconnected habitats, including coral reefs, seagrass meadows, estuaries and mangrove

4 creeks, and are amongst the most highly productive ecosystems globally (Moberg \& Folke

5 1999, Nagelkerken 2009). This interface between marine and terrestrial biomes is a dynamic

6 space, particularly in the tropics, supporting a range of species, which themselves are essential

7 to the function and health of ecosystems. Stingrays (Myliobatiformes) are ubiquitous and make

8 up a significant portion of fish biomass in these environments (O'Shea et al. 2012). Through

9 their foraging behavior, stingrays are significant agents of disturbance, physically modifying

10 the habitat through the excavation of infaunal prey, which they regulate by exerting top-down

11 control. As mesopredators, they are critical in creating links and energy transfer between lower and higher levels in food webs and may be considered keystone species in these environments

13 (O’Shea 2012).

15 Despite their ecological importance in biological communities, half of the 630 recognised 16 species of ray are considered data deficient by the IUCN (Dulvy et al. 2014), and this paucity of understanding can limit the design and implementation of effective conservation measures (Bland et al. 2015). Perhaps the most common species of stingray found in the tropical western Atlantic is the southern stingray (Hypanus americanus; hereafter referred to as SOST), a species widely distributed from the east coast of the USA to southeast Brazil (Grubbs et al. 2016). The southern stingray is important as a resource for eco-tourism, including supplementary feeding by snorkelers (Corcoran et al. 2013), but its trophic position and dietary preference is not well understood owing to a scarcity of broader trophic information. Previous studies have sampled stomach contents in limited numbers of southern stingrays (between two and 25), and suggested they are dietary generalists - predominantly consuming decapod and 
1 portunid crabs, annelid and polychaete worms and teleost fish (Bigelow \& Schroeder 1953,

2 Randall 1967, Snelson \& Williams 1981, Smith \& Herrnkind 1992, Gilliam \& Sullivan 1993,

3 Bowman et al. 2000, Tilley et al. 2013a).

4

5 Conversely, the Caribbean whiptail stingray (Styracura schmardae; also known as the Atlantic

6 chupare stingray and hereafter referred to as CAWH) has been the subject of recent taxonomic

7 scrutiny (Carvalho et al. 2016) with its contemporary distribution in The Bahamas only being

8 described relatively recently (O'Shea et al. 2017). Even the most basic life-history data are

9 lacking for this species, increasing the complexity of challenges when understanding the role

10 and ecology of large-bodied, mesopredators within the coastal tropical western Atlantic. This

11 species is similar in appearance to the southern stingray, and it may thus have been

12 misclassified in the past. The extent to which southern stingrays and Caribbean whiptail rays

13 may overlap in space and time and compete for resources is currently unknown, although field

14 observations have revealed that the two species are sympatric, in that they have been observed

15 at congruent sites. Understanding niche overlap and resource partitioning however, will be a

16 critical step in developing management and conservation strategies for these two species and

17 the ecosystems that support them.

19 Assessing stomach content via gastric flushing in living animals provides insight into temporally restricted prey preference, and dietary content (Hyslop 1980, Barnett et al. 2010, Heupel \& 21 Simpfendorfer 2010, O'Shea et al. 2017), although limited in resolution to that of an individual's last meal. In order to mitigate these limitations, muliple repeated sampling efforts can be conducted to obtain this information over time from the same locations and cohort of animals. In addition, more

24 forensic approaches can be employed, for example measuring the chemical signatures of resources integrated into consumer tissues, using stable isotope analysis can be a powerful tool when combined 
1 indicative estimates of resource use (Shiffman et al. 2012, Hammerschlag 2019) by measuring the ratios

2 of stable isotopes to standard forms of certain key elements, (N, C, H and O). While SIA cannot

3 demonstrate absolute estimates of diet (Robinson et al. 2018), when used with putative samples from

4 the environment, it can indicate likely dietary inputs (Phillips et al. 2014). In addition, the relative

5 temporal period over which different tissues (e.g. blood, skin and muscle) reflect diet depends on the

6 metabolic activity of the tissue sampled, for example, blood is more metabolically active than muscle

7 tissue, and stingray barbs, which are metabolically inert once synthesized, so preserve a permanent

8 isotopic signature until they erode or are shed (MacNeil et al. 2006). Because of this variability,

9 MacNeil et al. (2006) suggest that estimation of trophic dynamics from a single tissue (e.g. muscle) can

10 have considerable uncertainty. Thus in the present study, we use three different tissue types to compare

11 the diets of the two study species.

13 The overall objective of this study was to discern and describe prey preference and dietary 14 content in two sympatric species of stingray from multiple sites in the central Bahamas, and 15 reconciling dietary overlap and potential resource partitioning using a multi analytical approach. More specifically, we aimed to describe the diets of both species, investigate putative temporal patterns in diet over time between these species and compare results generated from both stomach content and stable isotope analyses. Further, we aimed to assess dietary preference within and between species according to sex and size class (ontogeny).

\section{MATERIALS and METHODS}

The islands of Eleuthera and the Exuma Cays lie in the central Bahamas archipelago in the tropical western Atlantic (Fig. 1), where mangrove creek, coral reef and soft sediment expanses provide an abundance of suitable habitat for stingrays (Aguiar et al. 2009, Garrone Neto \& 
1 over three geographic locations: i) the Schooner Cays $\left(24.9008^{\circ} \mathrm{N},-76.3703{ }^{\circ} \mathrm{W}\right)$, a group of

2 limestone islands surrounded by shallow sand flats of the Great Bahama Bank; ii) Powell Point,

3 Southern Eleuthera $\left(24.8317^{\circ} \mathrm{N} ;-76.3349^{\circ} \mathrm{W}\right)$ a Cape lined with shallow mangrove creek

4 inlets and with deep waters of the Exuma sound to the south; and iii) the Exuma Cays

$5 \quad\left(24.7177^{\circ} \mathrm{N},-76.8223^{\circ} \mathrm{W}\right)$, a chain of islands along the Great Bahama Bank. Capture sites

6 were selected following personal observations and capture success for a series of parallel

7 studies. Both species of ray were observed at all 23 sites, but were not encountered, and

8 therefore captured on the same day during the course of the study.

9

\subsection{Ray capture and tissue sampling}

Capture involved visually locating rays in shallow water $(<1 \mathrm{~m})$ from a boat, before herding them by wading on foot into a seine net $(10 \mathrm{~m} \times 1.5 \mathrm{~m})$, and encircling them into the net. Once an individual had been caught, a large dip net (1m diameter) was used to immobilise the stingray, which was then restrained by hand using puncture proof gloves, and the venomous barb secured with cloth and Velcro ${ }^{\mathrm{TM}}$ straps. Any pre-existing external identification tags were noted, and ray disc width (the distance between the two widest points of the stingray's pectoral fins, in $\mathrm{mm}$ ) was measured using a flexible measuring tape. Rays were sexed using the presence or absence of claspers to indicate males. All new captured individuals were tagged in the dorsal surface of the left pectoral fin with a new identification tag (Hallprint.com) bearing a unique identification number, and a subcutaneous passive integrated transponder (PIT) tag was also administered. Prior to tissue collection, stingrays were placed into tonic immobility via dorsoventral recumbence, resulting in a natural state of paralysis, which is thought to reduce stress during sampling procedures (Henningsen 1994). White muscle tissue samples $\left(\sim 1 \mathrm{~cm}^{2}\right)$ were taken from the pelvic fins using sterilized scissors. Blood (3 ml) was extracted from the caudal vein using an 18-gauge hypodermic needle. A cartilage clipping $\left(<1 \mathrm{~cm}^{2}\right)$ was taken from the 
1 tip of the barb using sterilized scissors. Samples were kept on ice in the field to retard

2 degradation of samples and once back at the lab were frozen immediately for storage. Prior to

3 stable isotope analysis, samples were thawed and oven dried at $70^{\circ} \mathrm{C}$ for 24 hours.

\subsection{Stomach content analysis (SCA)}

6 Gastric lavage was performed following methods outlined by O'Shea et al. (2017). Briefly, a

7 clean silicone tube $(\sim 10 \mathrm{~mm}$ diameter $)$ was inserted through the buccal cavity into the stomach

8 using an external marker on the ventral surface of the animal to visualise the location of the

9 oesophageal sphincter. Sixty millilitres of ambient seawater was then introduced to the stomach

10 via a syringe, and expelled stomach contents were captured in a tray lined with $1 \mathrm{~mm}$ mesh.

11 Individuals were considered to be 'empty' after three lavage attempts (max of $180 \mathrm{ml}$ of stomach flushing). Total wet mass of stomach contents was recorded to the nearest $0.1 \mathrm{~g}$. Any highly digested and/or unidentifiable prey items were weighed and inspected. The remaining prey items were identified to the lowest taxonomic resolution and grouped into five phyla (Arthropoda, Annelida, Sipuncula, Mollusca and teleost fish). For each identified prey group, the number of prey items were counted and weighed to the nearest $0.1 \mathrm{~g}$. Four metrics were used to describe prey; (i) numerical contribution $\left(\mathrm{N}_{\mathrm{C}} \%\right)$, calculated as total count of a given prey taxa / total count of all prey taxa x 100 (Hyslop 1980); (ii) gravimetric contribution $\left(\mathrm{W}_{\mathrm{C}}\right.$ $\%$ ), calculated as total mass (g) of a given prey taxa / total mass of all prey taxa x 100 (Hyslop, 1980); and (iii) the frequency of occurrence $\left(\mathrm{F}_{\mathrm{O}} \%\right)$, calculated as total count of stomachs containing a given prey taxa / total count of stomachs with identifiable content x 100 (Vaudo \& Heithaus 2011). Finally, (iv) $\mathrm{N}_{\mathrm{C}} \%, \mathrm{~W}_{\mathrm{C}} \%$ and $\mathrm{F}_{\mathrm{O}} \%$ were used to calculate an Index of Relative Importance (IRI (Pinkas et al. 1971)):

$$
I R I=\left(N_{c} \%+W_{c} \%\right) \times F_{o} \%
$$


2 The resulting IRI for each prey taxa $\left(\mathrm{IRI}_{\mathrm{i}}\right)$ was then calculated as a percentage (IRI\%) of the

3 sum total of all prey taxa IRI (IRI $\mathrm{I}_{\mathrm{t}}$ ), using the following equation (Cortés 1997):

$$
I R I \%=\left(I R I_{i} \div \sum I R I_{t}\right) \times 100
$$

7 In order to estimate whether the number of stingrays sampled was sufficient to have described

8 diet composition, the mean cumulative number of prey taxa found within lavage samples was

9 plotted against the number of stingrays sampled. The number of stingrays sampled was 10 considered to be sufficient when the curve reached an asymptote (Ferry et al. 1997).

\subsection{Stable isotope analysis (SIA)}

13 Based on the prey types recorded from stomach content analysis, prey samples $(n=100)$ were

14 opportunistically collected using small aquarium nets from all sites where stingrays were 15 captured (Arthropoda $n=64$, Annelida $n=14$, Sipuncula $n=10$ and Chordata $n=12$ ) for 16 context in stable isotope analyses. Tissue samples of both ray species and all prey items were 17 freeze dried, ground to a fine powder using a pestle and mortar, and weighed into tin cups to $0.70 \mathrm{mg} \pm 0.05 \mathrm{mg}$ (for sequential $\delta^{15} \mathrm{~N}$ and $\delta^{13} \mathrm{C}$ analysis). In a subset of 100 muscle samples, the powdered tissue was weighed into tin cups to $2.00 \mathrm{mg} \pm 0.05 \mathrm{mg}$ for $\delta^{34} \mathrm{~S}$ analysis. Earlier work suggested that chemical extraction of lipids and urea had no significant effect on $\delta^{15} \mathrm{~N}$ and $\delta^{13} \mathrm{C}$ values in southern stingrays and Caribbean whiptail rays (Shipley et al. 2017), likely because they occur at trace levels in rays (Tilley et al. 2013a), and thus we did not remove lipids or urea before analysis. Samples were combusted in an Elementar Pyrocube purge-andtrap elemental analyser run in nitrogen, carbon and sulphur (NCS) mode, interfaced with an 
1 Spectrometry Facility. Two international standards (United States Geological Survey L-

2 glutamic acid (USGS40, analytical precision $(S D) \delta^{13} \mathrm{C}=0.07 ; \delta^{15} \mathrm{~N}=0.16$ ) and IAEA-S-1, S-

32 and S-3 Silver Sulphides for $\delta^{34} \mathrm{~S}$ (analytical precision $(S D)=0.17,0.59$, and 1.46, 4 respectively) and three internal standards (methane sulphonamide/gelatine (MSAG2), 5 methionine/gelatine (M2) and sulphanilamide/gelatine (SAAG2)) were run alongside the 6 stingray samples for calibration and cross checking against other stable isotope analysis 7 centres. Stable isotope ratios of ${ }^{13} \mathrm{C}$ to ${ }^{12} \mathrm{C},{ }^{15} \mathrm{~N}$ to ${ }^{14} \mathrm{~N}$ and ${ }^{34} \mathrm{~S}$ to ${ }^{32} \mathrm{~S}$ are expressed with delta notation $(\delta)$ as parts per million (\%o) (McKinney et al., 1950), with resulting values representing the relative difference between isotopic ratios of the sample compared to a standard.

The R package Stable Isotope Mixing Models in R (SIMMR) (after Parnell et al. 2010) was used to model the proportional contribution of prey phyla to the diets of both southern stingrays and Caribbean whiptail rays $(\mathrm{n}=1000$ iterations per prey source), using muscle tissue samples collected from both stingray species. Arthropod prey isotopic values were highly correlated (Fig. 2), which makes discriminating between the contribution of the different prey groups challenging, so decapod shrimp, other decapods and other crustacea were grouped as 'arthropods' for further analyses. Following Dale et al. (2011), we used a single diet-tissue discrimination factor (DTDF's) of $+2.7 \%$ for $\delta^{15} \mathrm{~N}$, and $+0.9 \%$ for $\delta^{13} \mathrm{C}$ for stable isotope modelling, because a single consumer tissue type was used. This value has not been validated for either Caribbean whiptail rays or southern stingrays (see Hussey et al. 2011), indeed few studies to date appear to have validated DTDFs for specific elasmobranch species (Hussey et al. 2009, Kim et al. 2012) and highlight that DTDFs can vary considerably, even within a genus (Hussey et al. 2012). We therefore cautiously apply this DTDF, accepting that future validation work may improve upon the estimates in the present study. In addition, background isotopic ratios can vary within as well as between years (e.g Scholze et al. 2003), which introduces 
1 additional variability we were unable to account for. Ratios from muscle tissues were plotted

2 in two-dimensional isotopic space, with DTDF adjusted isotopic ranges of the prey phyla.

3 Sensitivity of SIMMR dietary proportion estimates to DTDFs was tested with model re-runs

4 adjusting $\delta^{15} \mathrm{~N}$ by 0.5 and $1.0 \%$, and adjusting $\delta^{13} \mathrm{C}$ by 0.5 and $1.0 \%$.

6 To test for dietary and habitat overlap between the two species, ellipses of isotopic space were

7 generated using the R package 'Stable Isotope Bayesian Ellipses in R' (SIBER; [Jackson et al.

8 2011]). Ellipses encompass a user-defined proportion of isotopic values, and the overlapping

9 area between two sets of isotope data can be used as a proxy for niche overlap between species

10 (Guzzo et al. 2013). Trophic levels for prey were estimated from previous studies (Cortés 1997,

11 Ebert \& Cowley 2003, Tilley et al. 2013a). Where no trophic level was available, the closest ecological substitute for the missing prey was used. Prey trophic levels were used to calculate trophic levels for CAWH and SOST using isotope data, following (Cortés 1999):

$$
T L_{K}=1+\left(\sum_{j=1}^{n} P_{j} \times T L_{j}\right)
$$

Where $T L_{K}$ is the trophic level of a consumer, $P_{j}$ is the proportional contribution of a select prey source from the consumers diet, $n$ is the total count of prey sources observed within the consumers' diet, and $T L_{j}$ is the trophic level of the selected prey source. This was repeated for both stingray species using prey proportion estimates from SIA.

\subsection{Methodological similarity}

The Czekanowski index of similarity (Feinsinger et al. 1981) was used to measure the agreement between SCA and SIA, and is calculated as: 


$$
C I=1-\left(0.5 \times\left(\sum_{i=1}^{n} P_{x_{i}}-P_{y_{i}}\right)\right)
$$

2 where $P_{x_{i}}$ (estimate of SCA method) and $P_{y_{i}}$ (estimate of SIA method) are the diet contribution

3 estimates of the $i$-th prey phylum and $\mathrm{n}$ is the total number of prey phyla identified. The CI

4 ranges from 0 to 1 , with 0 indicating disagreement between methods, and 1 indicating perfect agreement.

\subsection{Statistical analysis}

Differences between the two species, two sexes and between the capture sites, were tested

9 using Wilcoxon rank sum tests, and homogeneity of variance was tested using Fligner Killeen

10 tests with 'relative importance' as the response variable. The isotopic values of the three tissue

11 types were compared using ANOVA with repeated measures, so as to include repeated observations over time. Linear mixed effects models were used to test whether ray disc width, sex, season of capture or capture location influenced isotopic ratios and prey types consumed.

14 Locations were grouped into Eleuthera and the Exuma Cays as there was no obvious rationale to treat them at a finer scale. To investigate whether there was an shift in habitat use for either species of stingray based on size classes, break point analysis was used to identify the disc width at which any change points in $\delta^{15} \mathrm{~N}$ and $\delta^{13} \mathrm{C}$ occurred, using the $\mathrm{R}$ package 'strucchange'. Briefly, this tests for deviations of coefficients from one stable linear regression relationship to another (i.e. where there is a structural change in the relationship between two variables), and 'strucchange' allows to simultaneously compute multiple breakpoints in linear regression models (Bai \& Perron 2003).

23 All work (including stingray capture and tissue sampling) was undertaken under permits from

24 the Bahamian Department of Marine Resources, and complied with the University of Exeter 
MEPS-2019-08-003: R1

1 Research Ethics framework and ethical policy, and was approved by the College of Life and 2 Environmental Sciences (2016/1543 and 2016/1546). 


\section{3. RESULTS}

2 A total of 206 stingrays (94 Caribbean whiptail rays and 112 southern stingrays) were captured

3 between January 2015 and February 2017, and muscle samples were collected from 193

4 individuals for stable isotope analysis (92 CAWH, 101 SOST), along with 56 blood samples

5 (30 CAWH, 26 SOST) and 60 barb samples (30 CAWH, 30 SOST, sampling regime Fig. S1).

6 For CAWH, 49 were female and 46 were male, and 92 of the SOST were female and 20 were

7 male. CAWH ranged from $228 \mathrm{~mm}$ to $1,472 \mathrm{~mm}$ disc width (mean $629 \mathrm{~mm} \pm 283$ s.d.), whilst

8 SOST ranged from $342 \mathrm{~mm}$ to $1,102 \mathrm{~mm}$ disc width $(674 \mathrm{~mm} \pm 175)$. Female southern

9 stingrays were significantly larger than males (median $719 \mathrm{~mm} \pm 173 \mathrm{~mm}$ s.d. versus $517 \mathrm{~mm}$

$10 \pm 67$ mm s.d.; Wilcoxon rank sum; $\left.\mathrm{W}_{18,83}=1270, \mathrm{p}<0.01\right)$, but there was no difference

11 between sexes in Caribbean whiptail rays.

\subsection{Stomach content analysis}

14 Gastric lavage was performed on 74 stingrays, of which 47 provided stomach content samples

15 (SOST $\mathrm{n}=28$, CAWH $\mathrm{n}=19$, i.e. the remaining 27 rays had nothing in their stomachs). Prey

16 items were identified from five phyla (Table 1; Arthropoda, Annelida, Sipuncula, Chordata and Mollusca) and could be resolved to sub-phylum level in 129 prey items. Cumulative prey curves for each species reached asymptotes after approximately 30 southern stingrays and 20

Caribbean whiptail rays had been sampled, suggesting that a sufficient number had been surveyed to represent the diet of both species (Fig. S2). Southern stingrays consumed a majority of arthropod prey (present in all 47 stingrays that had prey in their stomachs, constituting 62\% of prey mass and $89 \%$ IRI, Table 1), in particular brachyuran crabs and penaeid shrimp (both present in $18 \%$ of rays). Teleost fish were observed in a third of rays sampled (constituting $8 \%$ by prey mass and $6 \%$ IRI). Southern stingrays had also consumed annelid and sipunculid worms, and two had consumed molluscs. Caribbean whiptail rays likewise consumed a 
1 majority of arthropod prey (present in all CAWH sampled, constituting 59\% of prey mass and

$270 \%$ IRI, Table 1), in particular a genus of snapping shrimp (Alpheus spp.), which contributed

3 almost a fifth of total prey mass and were present in nearly a third of the 19 CAWH sampled.

4 The next most important prey were annelid worms (present in $68 \%$ of stomachs sampled, 5 constituting $28 \%$ of prey mass and $27 \%$ IRI). Caribbean whiptail rays had also consumed 6 decapod crustacea (present in one quarter of $\mathrm{CAWH}$ ) and sipunculid worms (present in one 7 fifth of $\mathrm{CAWH}$ ) and one ray had consumed an un-identified teleost fish. It is not clear if this 8 was captured or incidentally consumed during bioturbation, which tends to attract small fishes 9 to the resultant bioturbated sediment. There were no molluscs in any CAWH stomach samples. 10 None of stingray sex, disc width and capture location predicted the likelihood that any 11 particular prey type was consumed in either species, with the exception of molluscs, which were predicted by capture location in southern stingrays (Table S2). However, this was driven by two of the 28 stingrays only, as none of the remaining 26 had consumed molluscs.

\subsection{Stable isotope analysis}

16 Stable isotope mixing models suggested that southern stingrays likely consumed mainly arthropods (mean $43 \% \pm 5$ s.d.), annelid worms $(41 \% \pm 4)$, teleost fish $(12 \% \pm 2)$, and sipunculid worms $(2 \% \pm 1)$, while Caribbean whiptail rays consumed approximately the same proportion of arthropods (mean proportion $48 \% \pm 6 \% \pm$ s.d.), annelid worms (45\% $\% 4$ ), and sipunculid worms (5 \pm 3 ) as SOST, but far fewer teleost fish (1\% $\%$, Fig. 2). Importantly, the putative prey samples collected did not cover the entire isotopic niche area (Fig. 2) suggesting that there may be additional prey species that both stingray species consume. Caribbean whiptail rays were predicted to feed at a marginally lower trophic level (TL 3.48) compared with southern stingrays (TL 3.51), based on isotope mixing models. The only variables affecting $\delta^{15} \mathrm{~N}$ were disc width and capture location in Caribbean whiptail rays, with larger rays 
1 foraging at higher trophic levels (lme disc width: $\mathrm{F}=21.86, \mathrm{P}<0.01$, location: $\mathrm{F}=7.801$,

$2 \mathrm{P}, 0.01$, Table S1), but with a small effect size (e.g. doubling disc width brought about only a

$320 \%$ increase in $\delta^{15} \mathrm{~N}$ (Fig. S3a). Capture location brought about an even smaller effect size,

4 with a 5\% difference between Eleuthera and Exuma (Fig. S3b). Likewise, the only variable

5 that predicted $\delta^{13} \mathrm{C}$ was capture location, with a difference of about $10 \%$ between locations ( $\mathrm{F}$

$6=7.267, \mathrm{p}<0.01$, Table S1, Fig. S3c), and $\delta^{34} \mathrm{~S}$ was not predicted by sex, season, capture

7 location or disc width. In southern stingrays, $\delta^{15} \mathrm{~N}$ varied by sex, with males foraging

8 approximately $1 \%$ higher than females $(F=9.67, p<0.01$, Fig. $S 3 d)$, and $\delta^{13} \mathrm{C}$ varied with disc

9 width, with larger rays foraging 2 to $3 \%$ lower $(F=12.14, p<0.01$, Table S1, Fig. S3e $) . \delta^{34} S$

10 was not predicted by sex, season capture or disc width.

12 Compared to SCA, SIA indicated a larger contribution of arthropods, yet provided higher estimates for the contribution of annelid worms to the diets of both species (Fig. 3). It also substantially increases the contribution of molluscs to southern stingray diets. Agreement between methods was generally poorer for southern stingrays than Caribbean whiptail rays -

16 SIA estimated that arthropods contributed four times less to diet compared to SCA, and molluscs four times more. Sipunculid worms were challenging to identify in gastric lavage samples, due to being soft bodied and easily digestible, but SIA suggested they were likely not important contributors to the diets of either species. Overall, there was a moderate to good agreement between dietary estimates from SIA and SCA for Caribbean whiptail rays. Of the three tissues sampled, dietary estimates from SIA of blood had the least agreement with SCA (Czekanowski index $(C I)=0.69)$, followed by barb $(C I=0.77)$, then white muscle $(C I=0.82)$. CI in southern stingrays varied from 0.94 for blood and SCA, followed by white muscle $(\mathrm{CI}=$ 24 0.48), and barb (CI = 0.33). 


\subsection{Inter-species differences}

2 Southern stingrays had greater $\delta^{15} \mathrm{~N}$ values in white muscle tissues $(6.77 \% \pm 1.07$ s.d. $)$ than

3 Caribbean whiptail rays $\left(4.82 \% \pm 1.06\right.$; Wilcoxon rank sum $\mathrm{W}_{96,102}=8493$, p < 0.001, Fig. 2)

4 and variances in $\delta^{15} \mathrm{~N}$ were similar for both species (Fligner-Killeen $\chi^{2}=0.0928, \mathrm{df}=1, \mathrm{p}=$

5 0.760). Southern stingrays also had greater $\delta^{13} \mathrm{C}$ values in white muscle tissues $(-8.76 \% \pm 1.05$

6 s.d.) than Caribbean whiptail rays $\left(-9.31 \% \pm 1.59\right.$; Wilcoxon rank sum $\mathrm{W}_{96,102}=6051.5, \mathrm{p}<$

7 0.01, Fig. 2), although the effect size was small (difference between means $0.55 \%$ ). Caribbean

8 whiptail rays had greater variance in $\delta^{13} \mathrm{C}$ than southern stingrays (1.59 versus 1.05 s.d.,

$9 \quad$ Fligner-Killeen $\left.\chi^{2}=13.6, \mathrm{df}=1, \mathrm{p}<0.001\right)$. Southern stingrays also had greater $\delta^{34} \mathrm{~S}$ in white 10 muscle tissues $\left(9.20 \%_{0} \pm 3.82\right.$ s.d. $)$ than Caribbean whiptail rays $\left(3.50 \%_{0} \pm 4.69\right.$; Wilcoxon rank 11 sum $\mathrm{W}=2068, \mathrm{p}<0.001)$, but with similar variance $\left(\right.$ Fligner-Killeen $\chi^{2}=1.89, \mathrm{df}=1, \mathrm{p}=$ 12 0.169). Caribbean whiptail rays had a larger isotopic niche space than southern stingrays (as 13 derived from SIBER, Fig. 4) for all combinations of $\delta^{13} \mathrm{C}, \delta^{15} \mathrm{~N}$ and $\delta^{34} \mathrm{~S}$, ranging from 5.82 to $\left.143.43 \%^{2}\right)$, although isotopic niche space overlapped in all cases by $35.6 \%\left(\delta^{13} \mathrm{C}\right.$ and $\left.\delta^{15} \mathrm{~N}\right)$, $15 \quad 41.1 \%\left(\delta^{34} \mathrm{~S}\right.$ and $\left.\delta^{15} \mathrm{~N}\right)$ and $61.5 \%\left(\delta^{34} \mathrm{~S}\right.$ and $\left.\delta^{13} \mathrm{C}\right)$.

\subsection{Inter-tissue differences}

18 Although the relative rate of isotopic turnover between blood, muscle and barb has yet to be determined for either Caribbean whiptail or southern stingrays, values should be likely to reflect temporal variation since each of the three tissues has a very different metabolic turnover (e.g. see MacNeil et al. 2006 for freshwater stingrays). In Caribbean whiptail rays, blood had the highest $\delta^{15} \mathrm{~N}$ (mean $5.16 \% \pm 0.851$ s.d.), followed by white muscle $(4.62 \% \pm \pm 1.20)$, then

24 (Fig. 5). In southern stingrays, there was no significant difference between blood (6.59 \% \pm 1.02) and white muscle $\delta^{15} \mathrm{~N}(6.70 \% \pm 1.12$, ANOVA with repeated measures $\mathrm{p}=0.888)$, but 
1 barb had significantly lower $\delta^{15} \mathrm{~N}(5.56 \% \pm 0.917)$ than either blood or muscle (ANOVA with

2 repeated measures $Z=11.3$, $p<0.001$, and $Z=11.6$, $p<0.001$, Fig. 5). In both species, blood had

3 the highest $\delta^{13} \mathrm{C}$ (Caribbean whiptail ray mean $11.8 \% \pm 1.28$ s.d., southern stingray $11.4 \% \pm$

4 1.46) followed by muscle (Caribbean whiptail ray $9.38 \% \pm \pm 1.62$, southern stingray $8.95 \% \pm \pm$

51.20 ) and then barb (Caribbean whiptail ray $8.37 \% \pm \pm 1.51$, southern stingray $8.22 \% \pm 1.37$ ).

6 However, we highlight that while inter-tissue comparisons suggest temporal differences in diet

7 (Shipley et al. 2017), knowledge of tissue-specific fractionation and enrichment factors are

8 almost absent for marine rays, so these values are presented for future utility, rather than as a

9 robust reflection of temporal variability in diet for these two species.

10

113.5 Ontogenetic changes

12 There were no breakpoints in $\delta^{15} \mathrm{~N}$ for southern stingrays in any of the three tissues, but $\delta^{13} \mathrm{C}$

13 decreased by approximately $2 \%$ in blood and muscle at $580 \mathrm{~mm}$ disc width $(95 \%$ confidence

14 interval: 468 to $609 \mathrm{~mm}$ ) and $705 \mathrm{~mm}$ disc width (595 to $745 \mathrm{~mm}$ ) respectively (Fig. 6).

15 Caribbean whiptail rays, by contrast, showed several breakpoints in both isotopes (Fig. 6).

16 Muscle $\delta^{15} \mathrm{~N}$ increased at $911 \mathrm{~mm}$ disc width (95\% confidence interval: 770 to $1201 \mathrm{~mm}$ ) by

17 almost $2 \%$, suggesting an increase in the trophic level at which they were foraging, but there were no changes in blood or barb. $\delta^{13} \mathrm{C}$ decreased in blood, muscle and barb at approximately 487, 568 and $503 \mathrm{~mm}$ disc width respectively, but by a smaller amount $(1.2,1.1$ and $1.7 \%$ o

20 respectively), then, at $815 \mathrm{~mm}$ disc width (95\% confidence interval 745 to $1,042 \mathrm{~mm}) \delta^{13} \mathrm{C}$ 21 increased again by $2.14 \%$, 


\section{4. DISCUSSION}

2 The present study is the first integrated diet reconstruction for southern stingrays using multiple

3 techniques, and the first ever diet assessment for the Caribbean whiptail ray. Arthropods and 4 annelid worms appear to make up the majority of prey for both southern stingrays and

5 Caribbean whiptail rays, and they feed more infrequently on other benthic, and largely sessile

6 prey. In comparison with previous studies of ray diet (Gilliam \& Sullivan 1993, Ebert \&

7 Cowley 2003, Flores-Ortega et al. 2011, Jacobsen \& Bennett 2012, 2013, Pardo et al. 2015),

8 these results are perhaps not surprising, but nevertheless are an important confirmation of the

9 prey preferences of these two data deficient species.

11 Southern stingrays appear to occupy a slightly higher trophic position than Caribbean whiptail rays but may have a similar dietary breadth. While both species occupy similar roles in the environment as mesopredators (Cortés, 1999) their diets likely overlap by one to two thirds; yet it remains unclear whether they compete for prey, or whether they can avoid it via temporal, spatial or microhabitat segregation (Schoener 1974). Caribbean whiptail rays likely feed on prey from a wider spatial distribution, potentially incorporating varying habitat, such as tidal mangrove creeks. Considering this species were captured over a much greater spatial extent than southern stingrays in the present study, this may explain some of the breadth of values.

There may also be some differences in the relative onshore-offshore foraging locations of the two species, but the difference may be ecologically negligible. Higher sulphur stable isotope values are often interpreted to indicate use of offshore, rather than estuarine, habitats (Barros et al. 2010). $\delta^{34} \mathrm{~S}$ in the present study thus suggests that southern stingrays either visit or use waters further offshore than Caribbean whiptail rays. Many elasmobranchs are also understood 
1 to exhibit ontogenetic habitat partitioning, typically within defined 'nursery' areas that offer

2 both shelter from predators and ample prey resources (Heupel et al. 2007).

4 Juvenile stingrays have been shown to inhabit mangrove and tidal creek areas (O'Shea et al.

5 2013) and adults will typically occupy offshore areas, with changes in carbon and sulphur

6 isotope values reflecting this. Whether southern stingrays use any of these strategies to avoid 7 competitive exclusion remains to be investigated; however, O'Shea et al. (2017) documented

8 different size classes of Caribbean whiptail rays in mangrove creeks compared with sand flats,

9 suggesting that mangroves may act as important refugia in the early developmental stages of 10 this species. Data presented here related to $\delta^{34} \mathrm{~S}$ further corroborates the theory that Caribbean 11 whiptail stingrays may occupy more coastal, estuarine environments. Furthermore, Caribbean whiptail rays will stay in the same creek for over three years (O'Shea et al. submitted) based on mark-recapture.

Sympatric species of ray have previously been demonstrated to segregate spatially, including southern stingrays and cownose rays in North Carolina, USA, (Bangley \& Rulifson 2017), and blue-spotted mask rays and blue-spotted fantail rays on Australian coral reefs (O'Shea et al. 2013). Similarly, species of skates have been shown to segregate by depth (Brickle et al. 2003); however temporal resource partitioning in rays appears to be less common (Gilliam \& Sullivan 1993, Corcoran et al. 2013).

\subsection{Consistency over time}

23 Using metabolically diverse tissues, the present study was able to gain some insight into longer 24 term patterns in resource use consistency in southern stingrays and Caribbean whiptail rays 25 (see also MacNeil et al. 2005, 2006), although it is important to note that tissue-specific diet 
1 tissue discrimination factors should be derived for future work, and DTDF will almost certainly

2 vary between the two species, and between tissues (Hussey et al. 2012). In addition, the isotopic

3 signatures of prey, as well as predators, can change over time (Inger \& Bearhop 2008), and we

4 were unable to account for this in the present study. Caribbean whiptail rays may switch to

5 forage on higher trophic level prey at around $900 \mathrm{~mm}$ disc width, which is thought to be around

6 half their maximum size (Cervigón et al. 1994), but there is no evidence of this in southern

7 stingrays. Estimated changes in foraging locations, however, may be more complex to discern

8 in the present study. First, the effect size of the change in $\delta^{13} \mathrm{C}$ between tissues is small in

9 Caribbean whiptails, which may indicate variability in foraging location or season, rather than

10 a net movement per se. Secondly, $\delta^{13} \mathrm{C}$ can be challenging to interpret, with $\delta^{13} \mathrm{C}$ increasing

11 from terrestrial areas to coastal waters because $\delta^{13} \mathrm{C}$ values of marine algae are much higher than terrestrial plants (Marshall et al. 2007), but then decreasing again moving offshore into

13 oligotrophic waters that tend to be less $\delta^{13} \mathrm{C}$ rich (Hobson et al. 1994). While size at maturity

14 for this species is still unknown, it is likely that these small shifts in $\delta^{15} \mathrm{~N}$ representing a transfer

15 to higher trophic prey at $900 \mathrm{~mm}$ disc width may reflect an ontogenetic shift; but further

16 investigation would be required to validate this, including size at maturity. Breakpoints in $\delta^{13} \mathrm{C}$ values for CAWH individuals is relatively well defined further lending validation that an ontogenetic shift in prey consumption may be occurring, but whether this is a result of growing

19 larger with subsequent access to larger prey, or if it represents a shift in habitat use and 20 association cannot be discerned without further investigation.

22 Given that stingrays in the present study likely move from mangroves (which extend into 23 terrestrial zones) to offshore cays, the direction of change in $\delta^{13} \mathrm{C}$ does not yet yield a clear 24 understanding of their movement. Further work assessing the differences in $\delta^{13} \mathrm{C}$ between these 25 habitats would help, as would tracking stingrays of both species, for example with acoustic 
1 telemetry, light geolocation tags or time depth recorders (Hussey et al. 2015) to assess the

2 extent to which they move within a normal season (Cartamil et al. 2003). It also remains

3 possible that some of the isotopic differences between the species are an artefact of the

4 locations at which they were captured, with Caribbean whiptail stingrays captured over a much

5 larger range than southern stingrays. The capture location may vary isotopically, but with few

6 putative prey samples from each, we were unable to robustly resolve this in the present study.

7 Further, it is unclear how far either southern stingrays or Caribbean whiptail rays move over

8 the scale of months to years (but see Tilley et al. 2013b) and how this may therefore affect the

9 integration of isotopic values, should they vary by site.

\subsection{Methodological aspects}

12 Studying the diet of wild sharks and rays has been predominantly approached using stomach content analysis (Hyslop 1980, Barnett et al. 2010, Heupel \& Simpfendorfer 2010). More recently stable isotope analysis has been adopted as a less invasive way to infer diet in wild animals (Hussey et al. 2012, Shiffman et al. 2012, Hammerschlag 2019). It is important to note that SIA alone does not determine diet, but rather reflects relative differences, and in combination with prey sampling, can infer likely composition. The present study highlights that there can be considerable differences in the results produced by SIA and stomach content analysis, although the most important prey taxa will likely still be resolvable. The present study parsimoniously concludes that arthropod and annelid prey are likely important for Caribbean whiptail and southern stingrays, but exact contributions to diet should not be inferred. Further experimental work is needed to parameterise the rate at which $\delta^{15} \mathrm{~N}$ and $\delta^{13} \mathrm{C}$ stable isotopes turn over in different tissue types in rays (e.g. MacNeil et al. 2005), which would improve

24 longer-term insights into diet. In addition, future studies should attempt to collect sufficient breadth of putative prey species to cover the entire isotopic niche area. 


\section{$1 \quad$ Conclusion}

2 Results presented here offer a critical insight into the trophic ecology and position between two

3 species of large bodied stingray from The Bahamas. Given that rays represent the most

4 vulnerable group of cartilaginous fishes globally (Dulvy et al. 2014), and the conservation

5 status of these species remains data deficient, this is a critical step in elucidating elements of

6 their life history to better inform the effective management of species and the habitats that

7 support them. This is particularly relevant for the Caribbean whiptail ray which is considered

8 rare throughout its known range (Nunes \& Nunes 2020), and provides the very first assessment

9 of its trophic ecology. Finally, understanding the dietary niche preferences of co-occurring

10 species allows for a better understanding when assessing the ecological gradients at which the

11 partitioning of resources occurs between and among tropical batoids.

\section{ACKNOWLEDGEMENTS}

14 Isotope analyses were supported by funding from the Natural Environment Research Council

15 (NERC) Life Sciences Mass Spectrometry Facility (LSMSF EK287-10/17 to MM and EW).

16 This work formed the basis of a Masters by Research by both MM and EW, and we are grateful

17 to Clive Trueman, Andrew Griffiths, Mario Espinoza and Stuart Bearhop for helpful examiner comments to the respective theses that improved the work considerably. MM and EW are grateful to volunteers and interns that helped in data collection: S. Burnside, R. Webb, G.

20 Cardoso, M. Eason, C. Terfloth, V. Herbert, C. Sullivan, C. Brown and C. Brown, and Cape

21 Eleuthera Island School students. MM and EW also thank Richard Inger for guidance in interpreting isotope data. The authors are grateful to two anonymous reviewers and the handling editor for constructive comments that improved the manuscript. 


\section{REFERENCES}

Aguiar AA, Valentin JL, Rosa RS (2009) Habitat use by Dasyatis americana in a south-western Atlantic oceanic island. Journal of the Marine Biological Association of the UK $89: 1147-1152$

Bai J \& Perron P (2003) Computation and Analysis of Multiple Structural Change Models, Journal of Applied Econometrics 18:1-22

Bangley CW, Rulifson RA (2017) Habitat partitioning and diurnal-nocturnal transition in the elasmobranch community of a North Carolina estuary. Bulletin of Marine Science 93:319-338

Barnett A, Redd KS, Frusher SD, Stevens JD, Semmens JM (2010) Non-lethal method to obtain stomach samples from a large marine predator and the use of DNA analysis to improve dietary information. Journal of Experimental Marine Biology and Ecology 393:188-192

Barros NB, Ostrom PH, Stricker CA, Wells RS (2010) Stable isotopes differentiate bottlenose dolphins off west-central Florida. Marine Mammal Science 26:324-336

Bigelow HB, Schroeder WC (1953) Fishes of the Gulf of Maine. In: US Government Printing Office Washington D (ed), Book 53

Bland LM, Collen B, Orme CDL, Bielby J (2015) Predicting the conservation status of datadeficient species. Conservation Biology 29:250-259

Bowman R, Stillwell C, Michaels W, Grosslein M (2000) Food of northwest Atlantic fishes and two common species of squid NOAA Technical Memorandum, Book NMFS-NE155

Brickle P, Laptikhovsky V, Pompert J, Bishop A (2003) Ontogenetic changes in the feeding habits and dietary overlap between three abundant rajid species on the Falkland Islands' 
shelf. Journal of the Marine Biological Association of the United Kingdom 83:11191125

Cartamil DP, Vaudo JJ, Lowe CG, Wetherbee BM, Holland KN (2003) Diel movement patterns of the Hawaiian stingray, Dasyatis lata: implications for ecological interactions between sympatric elasmobranch species. Marine Biology 142:841-847

Cervigón F, Cipriani R, Fischer W, Garibaldi L, Hendrickx M, Lemus AJ, Claro R (1994) Características generales de la ictiofauna. In: Claro R (ed) Ecología de los peces marinos de Cuba. Instituto de Oceanología de la Academia de Ciencias de Cuba y Centro de Investigaciones de Quintana Roo

Collins AB, Heupel MR, Hueter RE, Motta PJ (2007) Hard prey specialists or opportunistic generalists? An examination of the diet of the cownose ray, Rhinoptera bonasus. Marine and Freshwater Research 58:135-144

Corcoran MJ, Wetherbee BM, Shivji MS, Potenski MD, Chapman DD, Harvey GM (2013) Supplemental Feeding for Ecotourism Reverses Diel Activity and Alters Movement Patterns and Spatial Distribution of the Southern Stingray, Dasyatis americana. PLoS ONE 8:e59235

Cortés E (1997) A critical review of methods of studying fish feeding based on analysis of stomach contents: application to elasmobranch fishes. Canadian Journal of Fisheries and Aquatic Sciences 54:726-738

Cortés E (1999) Standardized diet compositions and trophic levels of sharks. ICES Journal of Marine Science 56:707-717

Cross RE, Curran MC (2000) Effects of feeding pit formation by rays on an intertidal meiobenthic community. Estuarine, Coastal and Shelf Science 51:293-298 
1 Dale J, Wallsgrove N, Popp BN, Holland KN (2011) Nursery habitat use and foraging ecology of the brown stingray Dasyatis lata determined from stomach contents, bulk and amino acid stable isotopes. Marine Ecology Progress Series 433

de Carvalho MR, Loboda TS, Da Silva JPCB (2016) (2016) A new subfamily, Styracurinae, and new genus, Styracura, for Himantura schmardae (Werner, 1904) and Himantura pacifica (Beebe \& Tee-Van, 1941) (Chondrichthyes: Myliobatiformes). Zootaxa 4175:201-221

DeNiro MJ, Epstein S (1981) Influence of diet on the distribution of nitrogen isotopes in animals. Geochim Cosmochim Acta 45:341-351

Dulvy NK, Fowler SL, Musick JA, Cavanagh RD, Kyne PM, Harrison LR, Carlson JK, Davidson LN, Fordham SV, Francis MP, Pollock CM (2014) Extinction risk and conservation of the world's sharks and rays. eLife 3:e00590

Ebert DA, Cowley PD (2003) Diet, feeding behaviour and habitat utilisation of the blue stingray Dasyatis chrysonota (Smith, 1828) in South African waters. Marine and Freshwater Research 54:957-965

Feinsinger P, Spears EE, \& Poole, RW (1981) A simple measure of niche breadth. Ecology, 62: $27-32$.

Ferry LA, Clark SL, Cailliet GM (1997) Food habits of spotted sand bass (Paralabrax maculatofasciatus, Serranidae) from Bahia de Los Angeles, Baja California. Bulletin of the Southern California Academy of Sciences 96:1-21

Flores-Ortega JR, Godínez-Domínguez E, González-Sansón G, Rojo-Vázquez JA, Corgos A, Morales-Jáuregui MY (2011) Feeding habits of three round stingrays (Rajiformes: Urotrygonidae) in the central Mexican Pacific. Ciencias Marinas 37:279-292 
1 Garrone Neto D, Uieda VS (2012) Activity and habitat use of two species of stingrays

(Myliobatiformes: Potamotrygonidae) in the upper Paraná River basin, Southeastern Brazil. Neotropical Ichthyology 10:81-88

Garvey JE, Whiles M (2019) Analysing diets. In: Garvey JE, Whiles M (eds) Trophic Ecology. CRC Press

Gilbert F, Bonin P, Stora G (1995) Effect of bioturbation on denitrification in a marine sediment from the West Mediterranean littoral. Hydrobiologia 304:49-58

Gilliam DS, Sullivan KM (1993) Diet and feeding habits of the southern stingray Dasyatis americana in the central Bahamas. Bulletin of Marine Science 52

Grubbs RD, Snelson FF, Piercy A, Rosa R, Furtado M (2016) Hypanus americanus. The IUCN Red List of Threatened Species, Book e.T60149A104123038

Guzzo MM, Haffner GD, Legler ND, Rush SA, Fisk AT (2013) Fifty years later: trophic ecology and niche overlap of a native and non-indigenous fish species in the western basin of Lake Erie. Biological Invasions 15:1695-1711

Haine OS, Ridd PV, Rowe RJ (2001) Range of electrosensory detection of prey by Carcharinus melanopterus and Himantura granulata. Marine and Freshwater Research 52: 291-296.

Hammerschlag N (2019) Quantifying shark predation effects on prey: dietary data limitations and study approaches. Endangered Species Research 38:147-151

Henningsen AD (1994) Tonic immobility in 12 elasmobranchs: use as an aid in captive husbandry. Zoo Biology 13:325-332

Heupel MR, Carlson JK, Simpfendorfer CA (2007) Shark nursery areas: concepts, definition, characterization and assumptions. Marine Ecology Progress Series 337:287-297

Heupel MR, Simpfendorfer CA (2010) Science or slaughter: need for lethal sampling of sharks. Conservation Biology 24:1212-1218 
1 Hobson KA, Piatt JF, Pitocchelli J (1994) Using stable isotopes to determine seabird trophic relationships. Journal of Animal Ecology 63:786-798

3 Hussey NE, Brush J, McCarthy ID, Fisk AT (2009) $\mathrm{d}^{15} \mathrm{~N}$ and $\mathrm{d}^{13} \mathrm{C}$ diet-tissue discrimination factors for large sharks under semi-controlled conditions. Comparative Biochemistry and Physiology, Part A 155:1-9

Hussey NE, Chapman DD, Donnelly E, Abercrombie DL, Fisk AT (2011) Finicky samples: an assessment of shark fin as a source material for stable isotope analysis. Limnol Oceanogr-Meth 9:524-532

Hussey NE, Kessel ST, Aarestrup K, Cooke SJ, Cowley PD, Fisk AT, Harcourt RG, Holland KN, Iverson SJ, Kocik JF, Mills Fleming JE, Whoriskey FG (2015) Aquatic animal telemetry: A panoramic window into the underwater world. Science 348:1255642

Hussey NE, MacNeil MA, Olin JA, McMeans BC, Kinney MJ, Chapman DD, Fisk AT (2012) Stable isotopes and elasmobranchs: tissue types, methods, applications and assumptions. Journal of Fish Biology 80:1449-1484

Hyslop EJ (1980) Stomach contents analysis - a review of methods and their application. Journal of Fish Biology 17:411-429

Inger R, Bearhop S (2008) Applications of stable isotope analyses to avian ecology. Ibis $150: 447-461$

Jackson AL, Parnell AC, Inger R, Bearhop S (2011) Comparing isotopic niche widths among and within communities: SIBER - Stable Isotope Bayesian Ellipses in R. Journal of Animal Ecology 80:595-602

Jacobsen IP, Bennett MB (2012) Feeding ecology and dietary comparisons among three sympatric Neotrygon (Myliobatoidei: Dasyatidae) species. Journal of Fish Biology $80: 1580-1594$ 
1 Jacobsen IP, Bennett MB (2013) A comparative analysis of feeding and trophic level ecology in stingrays (Rajiformes; Myliobatoidei) and electric rays (Rajiformes: Torpedinoidei). PLoS One 8:e71348

Kim SL, Casper DR, Galvan-Magana F, Ochoa-Diaz R, Hernandez-Aguilar SB, Kock PL (2012) Carbon and nitrogen discrimination factors for elasmobranch soft tissues based on a long-term controlled feeding study. Environmental Biology of Fishes 95:37-52

MacNeil MA, Drouillard KG, Fisk AT (2006) Variable uptake and elimination of stable nitrogen isotopes between tissues in fish. Canadian Journal of Fisheries and Aquatic Sciences 63:345-353

MacNeil MA, Skomal GB, Fisk AT (2005) Stable isotopes from multiple tissues reveal diet switching in sharks. Marine Ecology Progress Series 302:199-206

Marshall AD, Kyne PM, Bennett MB (2008) Comparing the diet of two sympatric urolophid elasmobranchs (Trygonoptera testacea Müller \& Henle and Urolophus kapalensis Yearsley \& Last): evidence of ontogenetic shifts and possible resource partitioning. Journal of Fish Biology 72:883-898

Marshall JD, Brookes JR, Lajtha K (2007) Sources of variation in the stable isotopic composition of plants. In: Michener R, Lajtha K (eds) Stable Isotopes in Ecologyand Environmental Sciences. Blackwell Publishing, Oxford

Meysman FJR, Middelburg JJ, Heip CHR (2006) Bioturbation: a fresh look at Darwin's last idea. Trends in Ecology \& Evolution 21:688-695

Michener RH, Kaufman L (2007) Stable isotope ratios as tracers in marine food webs: an update. Stable Isotopes in Ecology and Environmental science 2:238-282

Minagawa M, Wada E (1984) Stepwise enrichment of ${ }^{15} \mathrm{~N}$ along food chains: further evidence and the relation between $\delta^{15} \mathrm{~N}$ and animal age. Geochimica et Cosmochimica Acta 48:1135-1140 
1 Moberg F, Folke C (1999) Ecological goods and services of coral reef ecosystems. Ecological Economics 29:215-233

Nagelkerken I (2009) Evaluation of nursery function of mangroves and seagrass beds for tropical decapods and reef fishes: patterns and underlying mechanisms. In: Nagelkerken I (ed) Ecological connectivity among tropical coastal ecosystems. Springer, Dordrecht

Nunes AR and Nunes JLS (2020) The mystery of Styracura schmardae stingrays from the Brazilian Amazon coast. Examines Mar Biol Oceanogr. 3(2). EIMBO.000564.2020. DOI: 10.31031/EIMBO.2020.03.000564

O'Shea OR, Thums M, Van Keulen M, Kempster RM, Meekan MG (2013) Dietary partitioning by five sympatric species of stingray (Dasyatidae) on coral reefs. Journal of Fish Biology 82:1805-1820

O'Shea, O. (2012). The ecology and biology of stingrays (Dasyatidae) at Ningaloo Reef, Western Australia (Doctoral dissertation, Murdoch University).

O’Shea OR, Thums M, van Keulen M, Meekan M (2012) Bioturbation by stingrays at Ningaloo Reef, Western Australia. Marine and Freshwater Research 63:189-197

O’Shea OR, Ward C, Brooks E (2017) Range extension in Styracura (= Himantura) schmardae (caribbean whiptail stingray) from The Bahamas. Caribbean Naturalist 38:1-8

O’Shea OR, Wueringer BE, Winchester MM, Brooks EJ (2017) Comparative feeding ecology of the yellow ray Urobatis jamaicensis (Urotrygonidae) from The Bahamas. Journal of Fish Biology 92:73-84

Pardo SA, Burgess KB, Teixeira D, Bennett MB (2015) Local-scale resource partitioning by stingrays on an intertidal flat. Marine Ecology Progress Series 533:205-218

Parnell, A. C., Inger, R., Bearhop, S., \& Jackson, A. L. (2010). Source partitioning using stable isotopes: coping with too much variation. PloS one, 5(3), e9672. 
1 Peterson BJ, Fry B (1987) Stable Isotopes in Ecosystem Studies. Annual Review of Ecology and Systematics 18:293-320

3 Phillips DL, Inger R, Bearhop S, Jackson AL, Moore JW, Parnell AC, Semmens BX, Ward EJ (2014) Best practices for use of stable isotope mixing models in food web studies. Candian Journal of Zoology 92:823-835

6 Pinkas L, Oliphant MS, Iverson ILK (1971) Food habits of Albacore, Bluefin tuna, and Bonito 7 in Caifornia Waters. Fisheries Bulletin 152

Platell M, Potter I, Clarke K (1998) Resource partitioning by four species of elasmobranchs (Batoidea: Urolophidae) in coastal waters of temperate Australia. Marine Biology $131: 719-734$

Randall J (1967) Food Habits of Reef Fishes of the West Indies. Studies in Tropical Oceanography 5:665-847

Robinson BG, Franke A, Derocher AE (2018) Stable isotope mixing models fail to estimate the diet of an avian predator. The Auk 135:60-70

Schoener TW (1974) Resource partitioning in ecological communities. Science 185:27-39

Scholze M, Kaplan JO, Knorr W \& Heimann M (2003) Climate and interannual varibility of the atmosphere-biosphere ${ }^{13} \mathrm{CO}_{2}$ flux. Geophysical Research Letters 30:1097.

Shiffman DS, Gallagher AJ, Boyle MD, Hammerschlag-Peyer CM, Hammerschlag N (2012) Stable isotope analysis as a tool for elasmobranch conservation research: a primer for non-specialists. Marine \& Freshwater Research 63:635-643

Shipley ON, Murchie KJ, Frisk MG, Brooks EJ, O’Shea OR, Power M (2017) Low lipid and urea effects and inter-tissue comparisons of stable isotope signatures in three nearshore elasmobranchs. Marine Ecology Progress Series 579:233-238 
1 Smith K, Herrnkind W (1992) Predation on early juvenile spiny lobsters Panulirus argus (Latreille): influence of size and shelter. Journal of Experimental Marine Biology and Ecology 157:3-18

Snelson FJ, Williams S (1981) Notes on the occurrence, distribution, and biology of elasmobranch fishes in the Indian River Lagoon system, Florida. Estuaries 4:110-120

Summers AP, Koob TJ, Brainerd EL (1998) Stingray jaws strut their stuff. Nature 395: 450.

Tilley A, López-Angarita J, Turner JR (2013a) Diet Reconstruction and Resource Partitioning of a Caribbean Marine Mesopredator Using Stable Isotope Bayesian Modelling. PLOS ONE 8:e79560

Tilley A, López-Angarita J, Turner JR (2013b) Effects of scale and habitat distribution on the movement of the southern stingray Dasyatis americana on a Caribbean atoll. Marine Ecology Progress Series 482:169-179

Varghese SP, Somvanshi VS, Dalvi RS (2014) Diet composition, feeding niche partitioning and trophic organisation of large pelagic predatory fishes in the eastern Arabian Sea.

Vaudo JJ, Heithaus MR (2011) Dietary niche overlap in a nearshore elasmobranch mesopredator community. Marine Ecology Progress Series 425:247-260

White WT, Potter IC (2004) Habitat partitioning among four elasmobranch species in nearshore, shallow waters of a subtropical embayment in Western Australia. Marine

Zajac RN (2004) Macrofaunal responses to pit-mound patch dynamics in an intertidal mudflat: local versus patch-type effects. Journal of Experimental Marine Biology and Ecology 


\section{FIGURES}

2

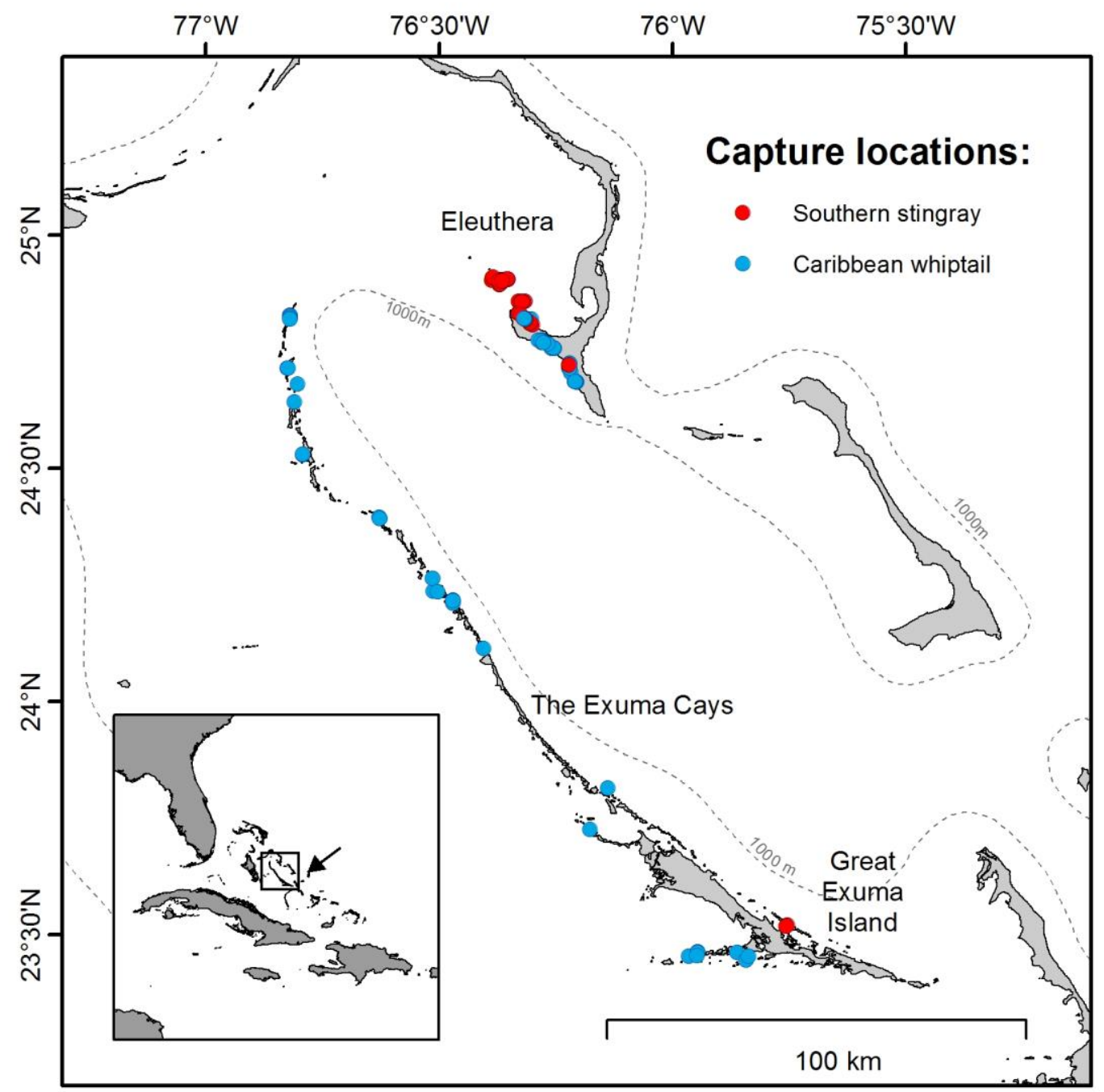

4 Figure 1: Map showing the capture locations of Caribbean whiptail rays (blue points) and

5 southern stingrays (red points) at sites surrounding the Exuma Cays, and Eleuthera, The

6 Bahamas. 

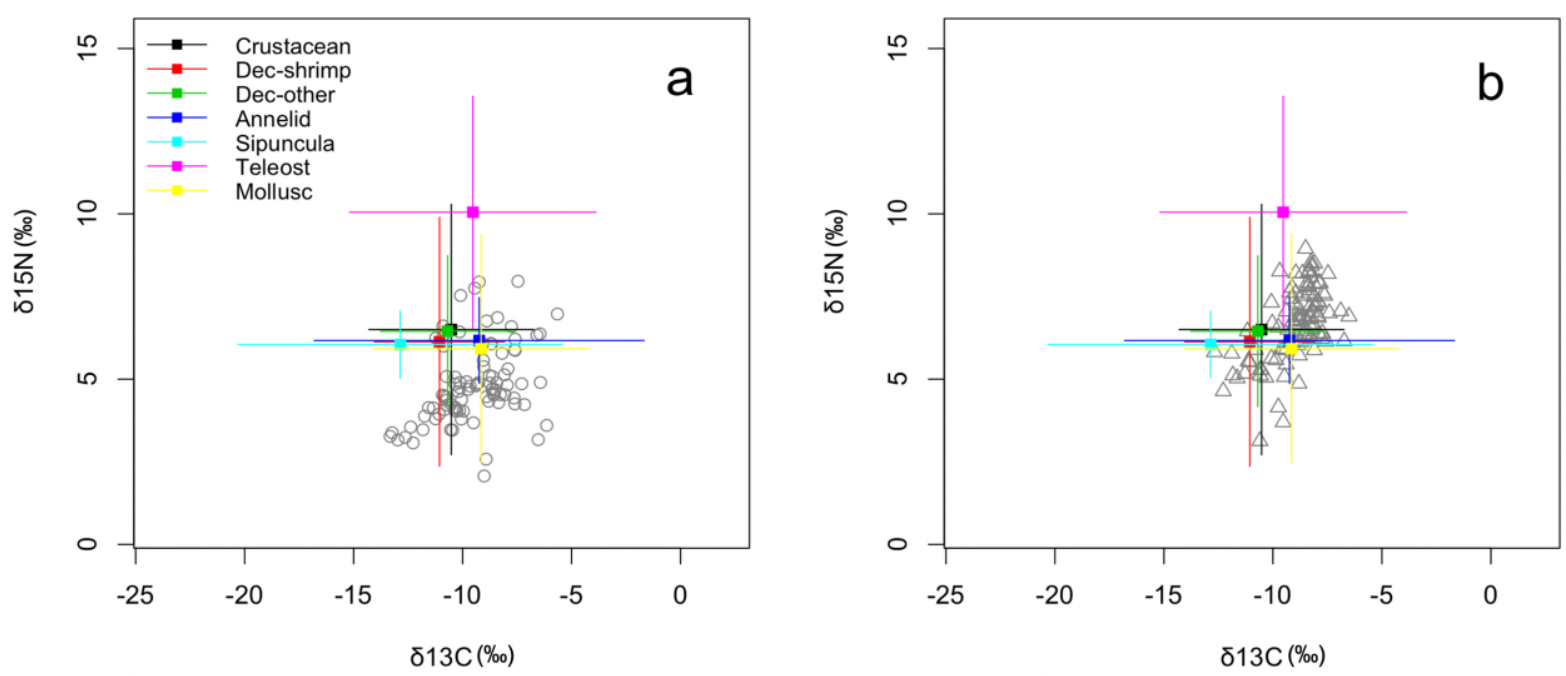

2

3 Figure 2: Bivariate scatter plot of $\delta^{15} \mathrm{~N}$ and $\delta^{13} \mathrm{C}$ values for white muscle samples from (a)

4 Caribbean whiptail rays and (b) southern stingrays, after applying a diet tissue discrimination

5 factor of $+2.7 \%$ for $\delta^{15} \mathrm{~N}$, and $+0.9 \%$ for $\delta^{13} \mathrm{C}$. The $\delta^{15} \mathrm{~N}$ and $\delta^{13} \mathrm{C}$ values (mean \pm s.d. in

6 both dimensions) for seven putative prey groups (Decapod shrimp, other decapods and other

7 crustacea are detailed separately, but grouped elsewhere as arthropods) from samples collected

8 at the same time and locations as the rays were captured are shown (Arthropoda in black, red

9 and green, Annelida in dark blue, Sipuncula in turquoise, Teleost fish in pink and Mollusca in 10 yellow). 

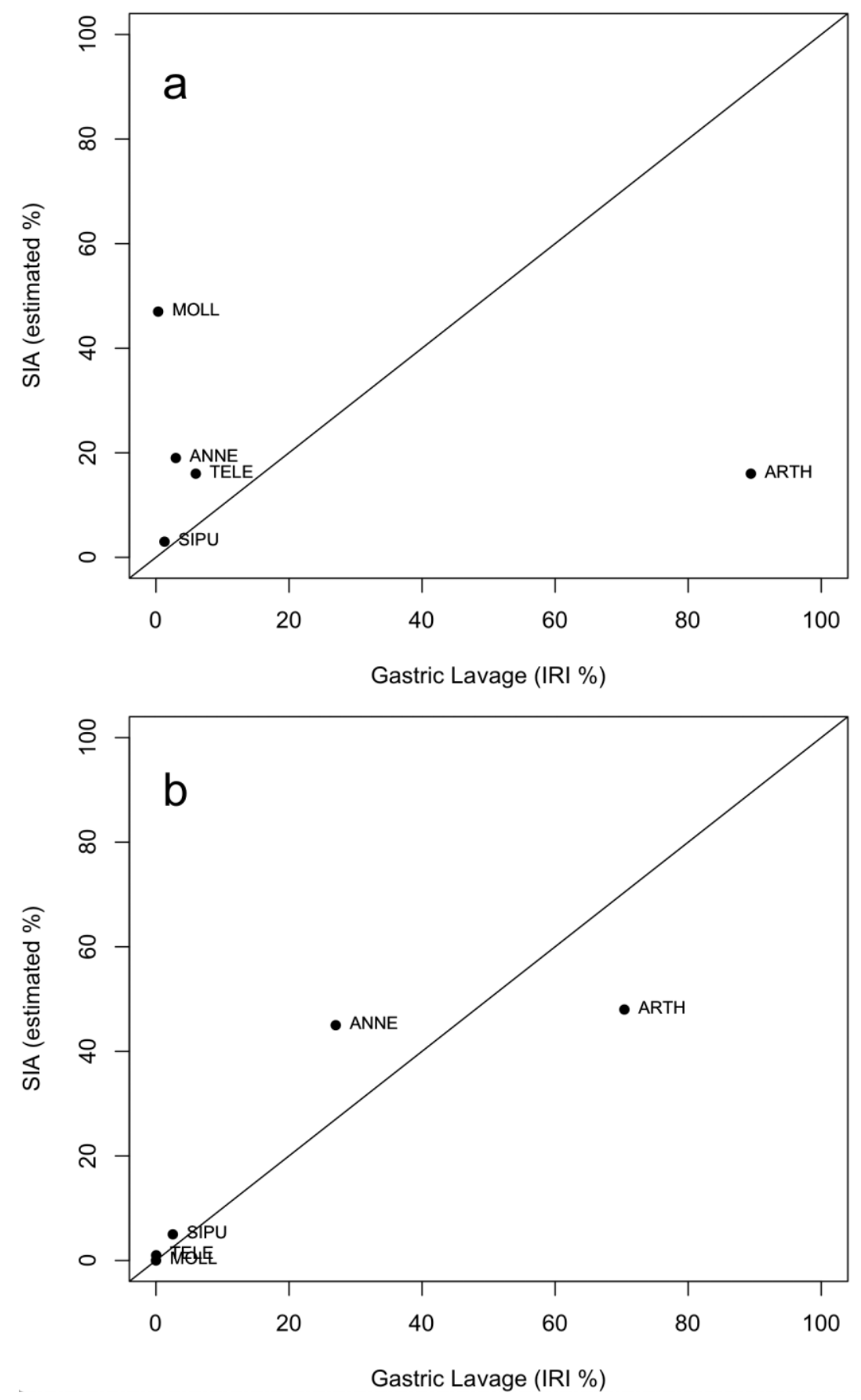

2 Figure 3. Plot showing estimated importance of five prey phyla $($ ARTH $=$ arthropods, ANNE $3=$ annelid worms, SIPU $=$ Sipunculid worms, TELE $=$ teleost fish and MOLL $=$ molluscs $)$ 4 estimated by SCA and SIA for a) Southern stingrays and b) Caribbean whiptail rays. Diagonal 5 line shows line of equivalence, where SCA and SIA would produce the same result. 

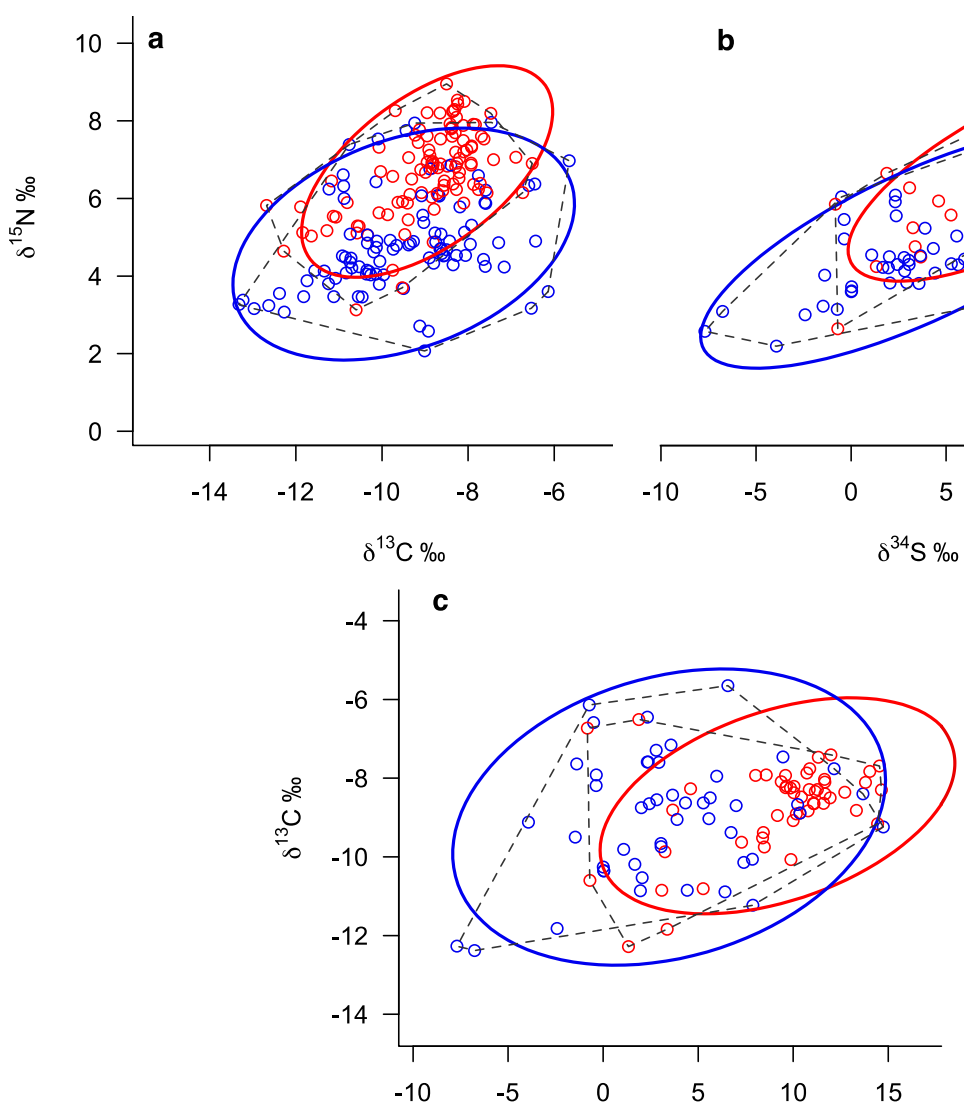

2 Figure 4: Bivariate isotope plots showing Standard Ellipses of isotopic spaces from white

3 muscle samples of Caribbean whiptail rays (blue) and southern stingrays (red) for (a) $\delta^{13} \mathrm{C}$ and

$4 \quad \delta^{15} \mathrm{~N}$, (b) $\delta^{15} \mathrm{~N}$ and $\delta^{34} \mathrm{~S}$, and (c) $\delta^{13} \mathrm{C}$ and $\delta^{34} \mathrm{~S}$. Solid lines enclose standard ellipse areas (SEA)

5 for each species which could be used to represent the total isotopic space occupied by each

6 species. Dashed lines represent convex hulls which encompass all data points for each species. 


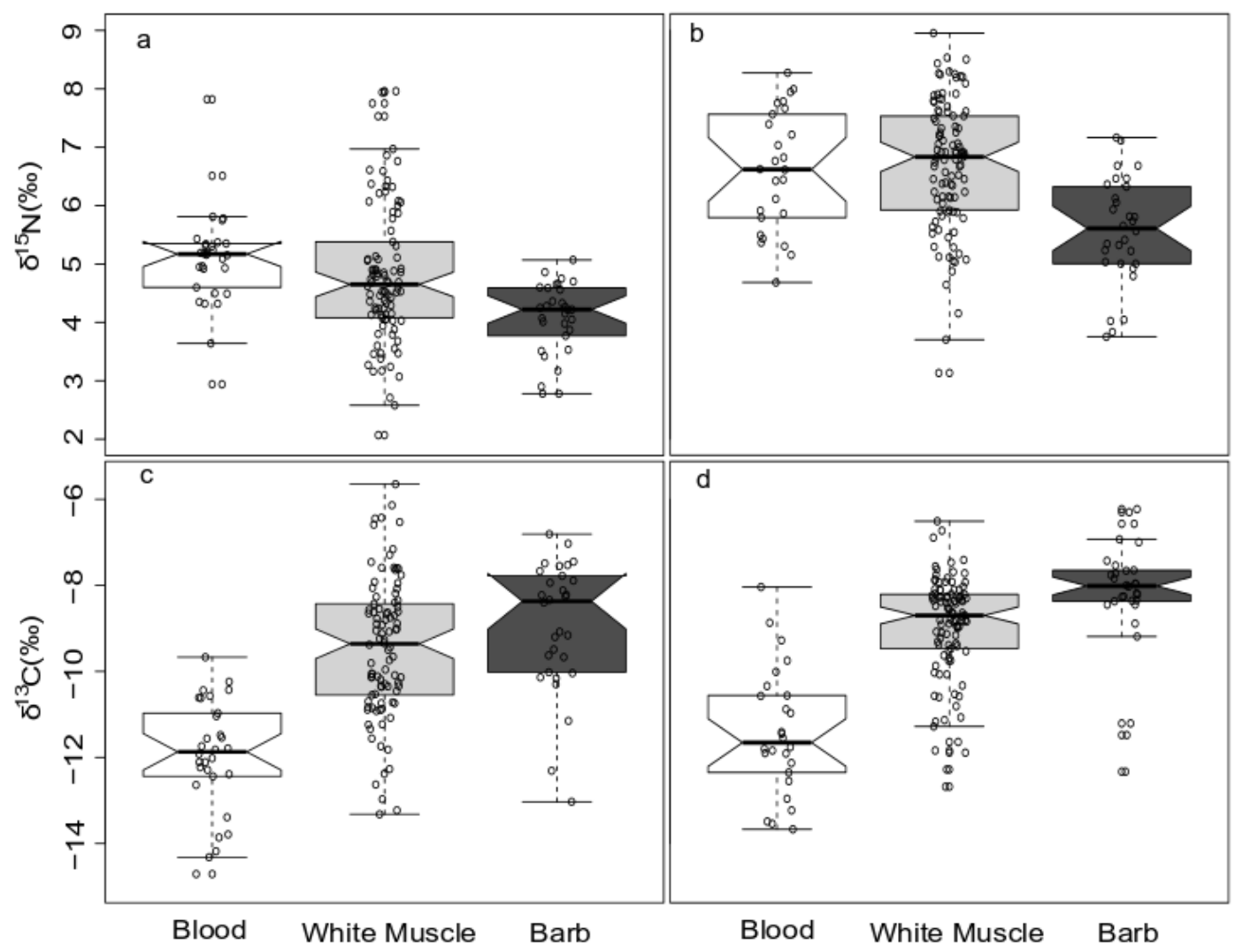

1

2 Figure 5: Boxplots showing the distribution of $\delta^{15} \mathrm{~N}(\mathrm{a}$ and $\mathrm{b})$ and $\delta^{13} \mathrm{C}(\mathrm{c}$ and $\mathrm{d})$ isotope values

3 for Caribbean whiptail ray (left) and southern stingray (right) blood (white), white muscle (light

4 grey), and barb (dark grey) tissues. Boxes show interquartile ranges, horizontal line shows

5 median value and notches indicate statistical differences. 

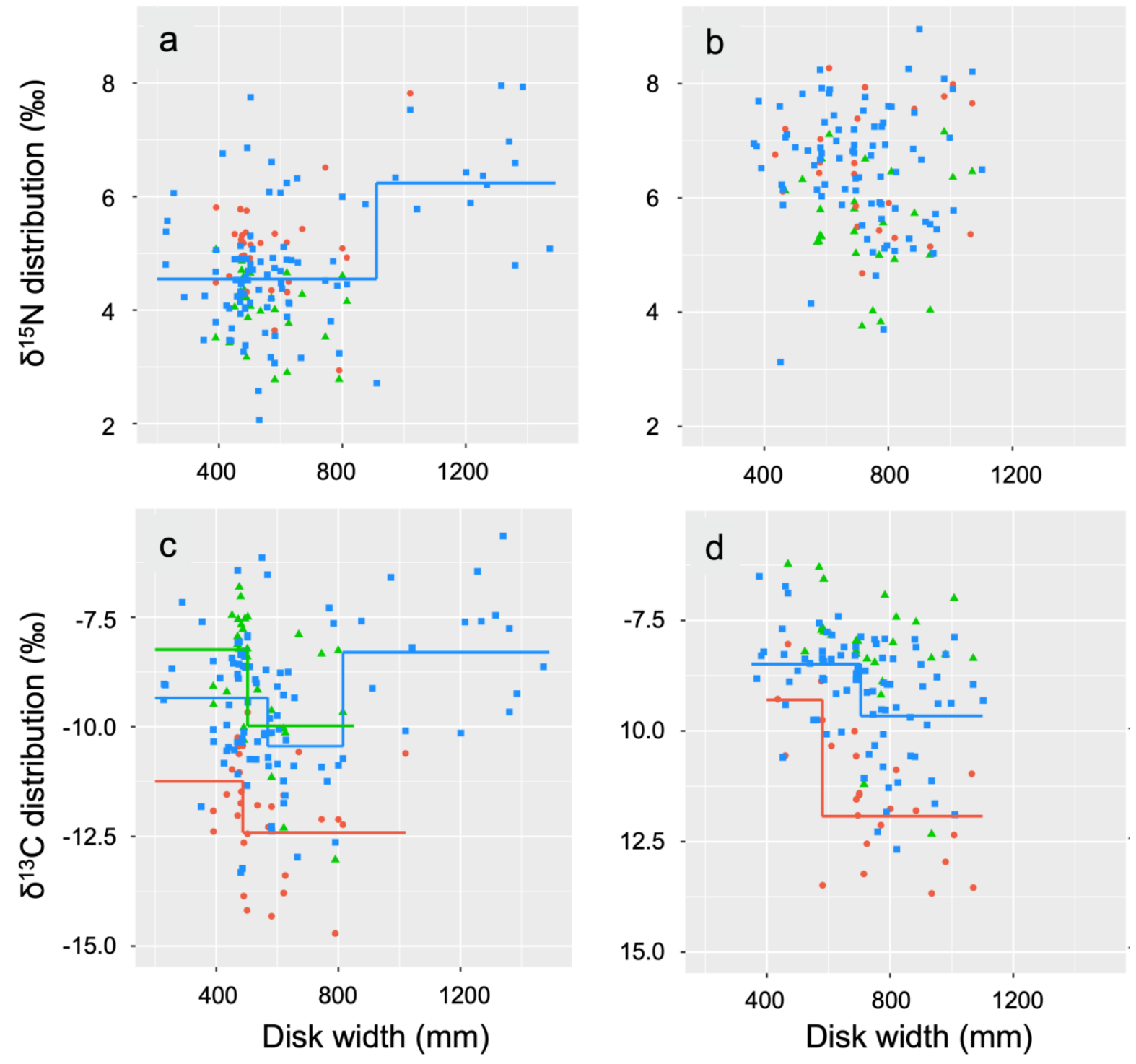

$3 \quad$ Figure 6: Scatterplots showing breakpoints in $\delta^{15} \mathrm{~N}$ (top row) and $\delta^{13} \mathrm{C}$ (bottom row) and disc

4 width for Caribbean whiptail rays (left panel) and southern stingrays (right panel). Points of

5 different shape and colour depict muscle (blue squares), blood (red circles), and barb (green

6 triangles). Breakpoints are demonstrated by vertical changes in solid lines (disc width point at

7 which the mean isotopic value shifts). 
1 Table 1: Dietary compositions of Caribbean whiptail rays and southern stingrays as from 2 stomach content analysis. Identified prey items are listed below the appropriate phylum and 3 noted with the lowest taxonomic level to which they were identified; phylum (p), sub-phylum 4 (s-p), infraclass (ic), order (o), infraorder (io), family (f) and genus (g). Prey proportions are 5 represented as percentage numerical composition $\left(\mathrm{N}_{\mathrm{c}} \%\right)$, percentage weight composition $\left(\mathrm{W}_{\mathrm{c}}\right.$ $6 \%)$, percentage frequency of occurrence $\left(\mathrm{F}_{\mathrm{o}} \%\right)$, and overall percentage index of relative 7 importance (IRI \%). 
MEPS-2019-08-003: R1

\begin{tabular}{|c|c|c|c|c|c|c|c|c|}
\hline \multirow{3}{*}{$\begin{array}{l}\text { Arthropoda } \\
\text { A }\end{array}$} & \multicolumn{4}{|c|}{ Caribbean whiptail rays } & \multicolumn{4}{|c|}{ Southern stingrays } \\
\hline & \multirow{2}{*}{$\begin{array}{l}N_{c} \% \\
51.38\end{array}$} & $W_{c} \%$ & $F_{o} \%$ & \multirow{2}{*}{ IRI\% } & \multirow{2}{*}{$\begin{array}{r}N_{c} \% \\
67.57\end{array}$} & $W_{c} \%$ & $\boldsymbol{F}_{\boldsymbol{o}} \%$ & IRI\% \\
\hline & & 58.63 & 100 & & & 62.46 & 100 & 89.43 \\
\hline Crustacea $^{(s-p)}$ & 1.83 & 2.30 & 10.53 & 0.69 & 17.57 & 16.56 & 35.71 & 32.28 \\
\hline Stomatopoda ${ }^{(0)}$ & 2.75 & 1.92 & 10.53 & 0.78 & 6.76 & 1.91 & 14.29 & 3.28 \\
\hline Decapoda $^{(0)}$ & 18.35 & 13.09 & 26.32 & 13.06 & 1.35 & 3.32 & 3.57 & 0.44 \\
\hline Brachyura (io) & 3.67 & 1.65 & 10.53 & 0.88 & 10.81 & 5.46 & 17.86 & 7.69 \\
\hline Portunidae $^{(\mathrm{f})}$ & 0 & 0 & 0 & 0 & 5.41 & 2.60 & 14.29 & 2.02 \\
\hline Diogenidae $^{(\mathrm{f})}$ & 0 & 0 & 0 & 0 & 1.35 & 0.33 & 3.57 & 0.16 \\
\hline Palaemonidae $^{(\mathrm{f})}$ & 6.42 & 16.13 & 15.79 & 5.62 & 5.41 & 3.07 & 10.71 & 2.40 \\
\hline Penaeidae ${ }^{(\mathrm{f})}$ & 0.92 & 4.23 & 5.26 & 0.43 & 9.46 & 16.00 & 17.86 & 12.04 \\
\hline Alpheus sp. ${ }^{(\mathrm{g})}$ & 17.43 & 19.30 & 31.58 & 18.31 & 5.41 & 5.50 & 3.57 & 1.03 \\
\hline Metapenaeopsis sp. ${ }^{(\mathrm{g})}$ & 0 & 0 & 0 & 0 & 4.05 & 7.72 & 7.14 & 2.23 \\
\hline Annelida & 40.37 & 27.83 & 68.42 & 27.02 & 10.81 & 4.37 & 21.43 & 2.98 \\
\hline Annelida (p) & 29.36 & 26.68 & 57.89 & 51.22 & 10.81 & 4.37 & 21.43 & 8.62 \\
\hline Arenicolidae $^{(\mathrm{f})}$ & 11.01 & 1.15 & 10.53 & 2.02 & 0 & 0 & 0 & 0 \\
\hline Mollusca & $\mathbf{0}$ & $\mathbf{0}$ & $\mathbf{0}$ & $\mathbf{0}$ & 2.10 & 5.91 & 7.14 & $\mathbf{0 . 3 3}$ \\
\hline Mollusca $^{(p)}$ & 0 & 0 & 0 & 0 & 2.70 & 5.91 & 7.14 & 1.63 \\
\hline Sipuncula & 7.34 & 13.41 & 21.05 & 2.53 & 5.41 & 19.51 & 10.71 & 1.28 \\
\hline Sipuncula ${ }^{(p)}$ & 7.34 & 13.41 & 21.05 & 6.90 & 5.41 & 19.51 & 10.71 & 7.07 \\
\hline Chordata & 0.92 & $\mathbf{0 . 1 3}$ & 5.26 & $\mathbf{0 . 0 3}$ & 13.51 & 7.75 & 32.14 & 5.98 \\
\hline Teleostei (ic) & 0.92 & 0.13 & 5.26 & 0.09 & 13.51 & 7.75 & 32.14 & 18.10 \\
\hline
\end{tabular}




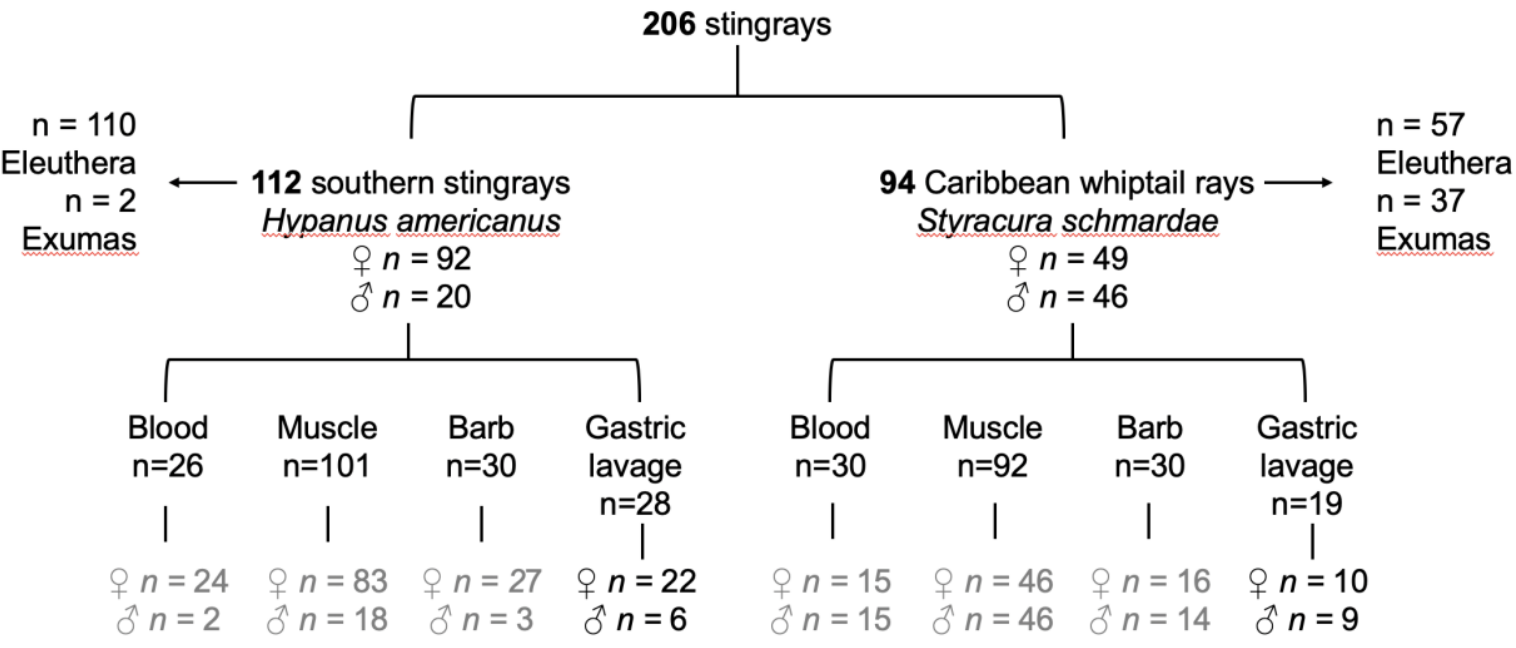

2

3 Figure S1: Sampling regime and sample numbers of southern stingrays and Caribbean whiptail

4 rays for stable isotope analysis (all samples except 'gastric lavage'). A subset of 100 ray muscle

5 samples (48 Caribbean whiptail and 52 southern stingrays) were analysed for $\delta^{34} \mathrm{~S}$. 

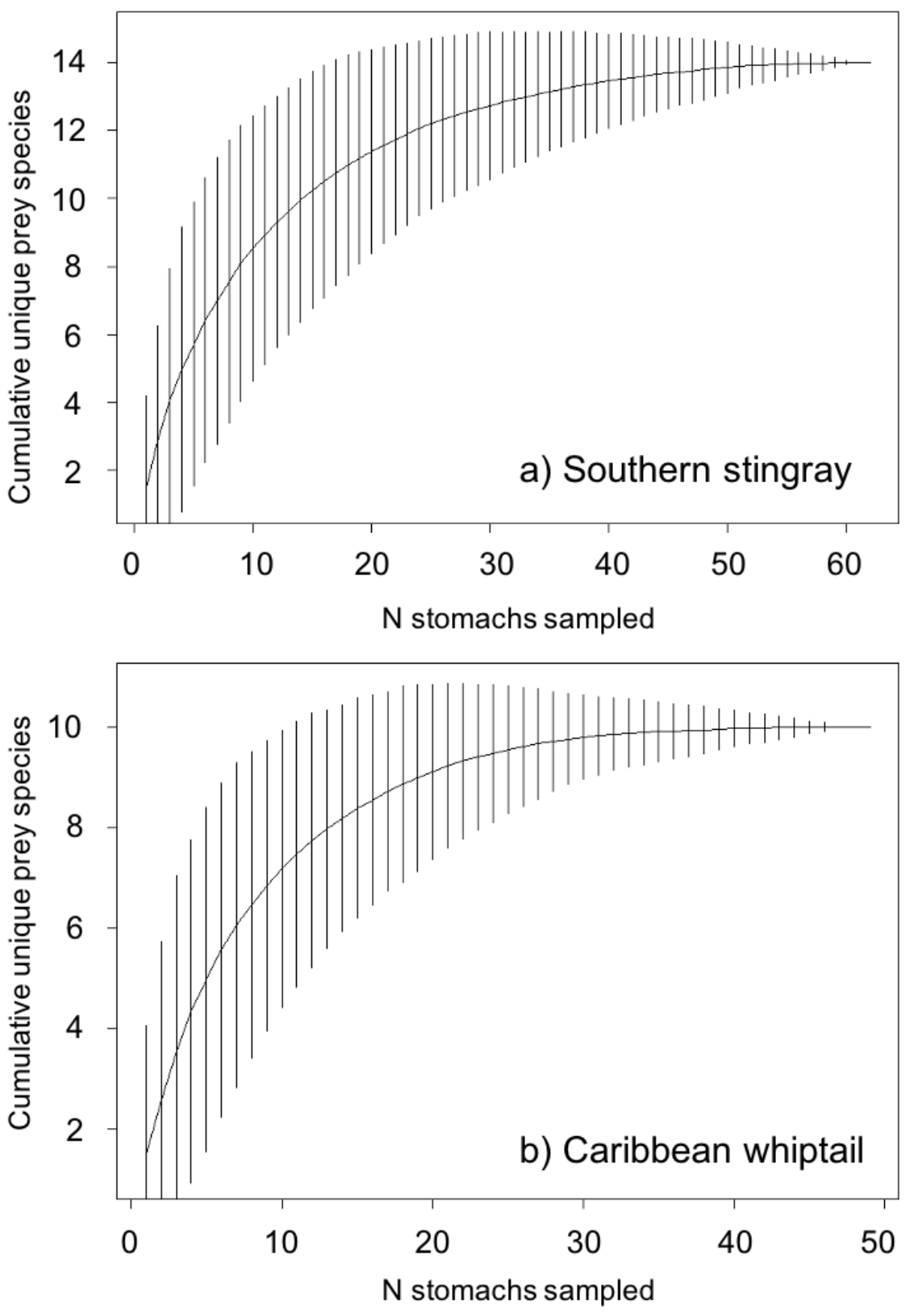

1

2 Figure S2. Plots showing the mean cumulative number of unique prey species discovered after

3 sampling stomach contents of a) southern stingrays and b) Caribbean whiptail stingrays. The

4 order in which individuals were sampled was randomised, and the number of cumulative

5 unique prey discovered was resampled 1000 times, and the mean value calculated across runs.

6 Vertical bars denote standard deviation around each mean value. A sufficient number of

7 sampled stomachs is represented with an asymptote in the graphs curve (Ferry et al. 1997). 

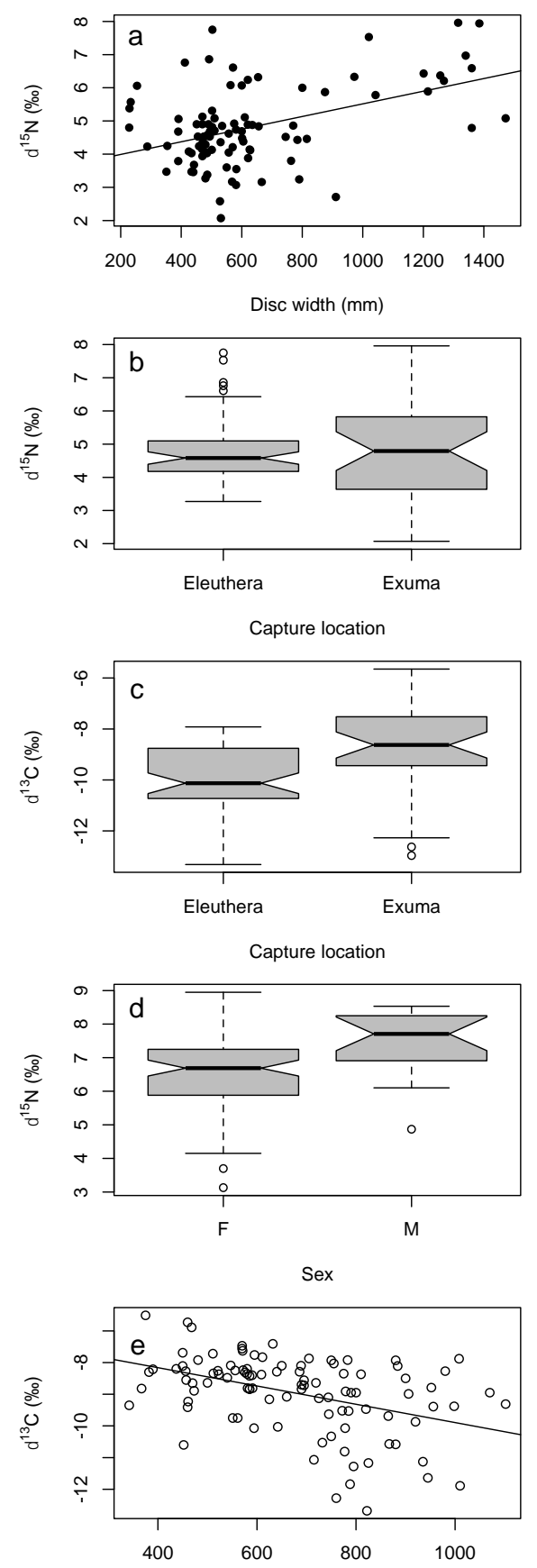

1

Disc width (mm)

2 Figure S3: The relationship between stingray disc width (in mm, a, e), capture location (b, c)

3 or sex (d) and $\delta^{15} \mathrm{~N}$ and $\delta^{15} \mathrm{~N}$ isotope values in white muscle of Caribbean whiptail rays (a, b,

4 c) and southern stingrays (d, e), showing variables that significantly predict isotope values (see

5 also Table S1). Parts (b, c and d) are boxplots, where notches indicate statistically significant

6 differences between the two datasets. Lines on (a) and (e) show significant least squared linear

7 regression relationships. 
1 Table S1: Linear modelling of factors (sex, season of capture, disc width and Island) that influence isotopic values of $\delta^{15} \mathrm{~N}, \delta^{13} \mathrm{C}$ and $\delta^{34} \mathrm{~S}$ from white muscle tissue. Bold text indicates statistical significance. Island was not used in linear modelling for southern stingrays because only two of 112 were caught outside of Eleuthera.

\begin{tabular}{|c|c|c|c|c|c|c|}
\hline & \multicolumn{2}{|l|}{$\delta^{15} \mathrm{~N}$} & \multicolumn{2}{|l|}{$\delta^{13} \mathrm{C}$} & \multicolumn{2}{|l|}{$\delta^{34} \mathrm{~S}$} \\
\hline & $\mathrm{F}$ & p-value & $\mathrm{F}$ & p-value & $\mathrm{F}$ & $\mathrm{p}$-value \\
\hline \multicolumn{7}{|c|}{ Southern stingray } \\
\hline Sex & 9.67 & $<0.01$ & 0.981 & 0.324 & 0.269 & 0.606 \\
\hline $\begin{array}{l}\text { Season of } \\
\text { capture }\end{array}$ & 3.367 & 0.069 & 1.902 & 0.171 & 0.417 & 0.522 \\
\hline Disc width & 0.014 & 0.907 & 12.137 & $<0.01$ & 0.239 & 0.627 \\
\hline Island & $(-)$ & $(-)$ & $(-)$ & $(-)$ & $(-)$ & $(-)$ \\
\hline \multicolumn{7}{|c|}{ Caribbean whiptail } \\
\hline Sex & 0.699 & 0.405 & 0.014 & 0.907 & 1.041 & 0.313 \\
\hline $\begin{array}{l}\text { Season of } \\
\text { capture }\end{array}$ & 3.274 & 0.074 & 0.332 & 0.566 & 1.351 & 0.251 \\
\hline Disc width & 30.112 & $<0.01$ & 1.206 & 0.275 & 0.923 & 0.342 \\
\hline Island & 7.807 & $<0.01$ & 7.267 & $<0.01$ & 1.770 & 0.190 \\
\hline
\end{tabular}


1 Table S2: Linear modelling of factors (sex, season of capture, disc width and Island) that influence the relative importance of Arthropods, Annelid worms, molluscs, sipunculid worms and teleost fish to the diets of southern stingrays and Caribbean whiptail rays as determined from stomach content analysis. Bold text indicates statistical significance. Mollusca was not used in linear modelling for Caribbean whiptail rays because they were no identified in any stomach samples.

\begin{tabular}{|c|l|l|l|l|l|l|l|l|l|l|}
\hline & \multicolumn{2}{|l|}{ Arthropoda } & \multicolumn{2}{l|}{ Annelida } & \multicolumn{2}{l|}{ Mollusca } & \multicolumn{2}{l|}{ Sipunculid } & \multicolumn{2}{l|}{ Teleost } \\
& F & p-value & F & p-value & F & p-value & F & p-value & F & p-value \\
\hline
\end{tabular}

\section{Southern stingray}

\begin{tabular}{|l|c|c|c|c|c|c|c|c|c|c|}
\hline Sex & 0.576 & 0.455 & 1.992 & 0.171 & 0.044 & 0.835 & 2.661 & 0.116 & 0.010 & 0.919 \\
\hline Disc width & 1.231 & 0.278 & 0.112 & 0.741 & 1.657 & 0.210 & 0.417 & 0.525 & 0.746 & 0.397 \\
\hline Island & 0.177 & 0.678 & 0.060 & 0.809 & $\mathbf{5 . 6 2 4}$ & $<\mathbf{0 . 0 5}$ & 0.023 & 0.880 & 0.249 & 0.622 \\
\hline
\end{tabular}

\section{Caribbean whiptail ray}

\begin{tabular}{|l|c|c|c|c|c|c|c|c|c|c|}
\hline Sex & 0.585 & 0.456 & 1.839 & 0.195 & $(-)$ & $(-)$ & 1.266 & 0.278 & 0.780 & 0.391 \\
\hline Disc width & 4.359 & 0.054 & 3.429 & 0.084 & $(-)$ & $(-)$ & 0.491 & 0.494 & 0.423 & 0.530 \\
\hline Island & 0.151 & 0.703 & 1.267 & 0.278 & $(-)$ & $(-)$ & 1.295 & 0.273 & 0.084 & 0.777 \\
\hline
\end{tabular}

$$
7
$$

